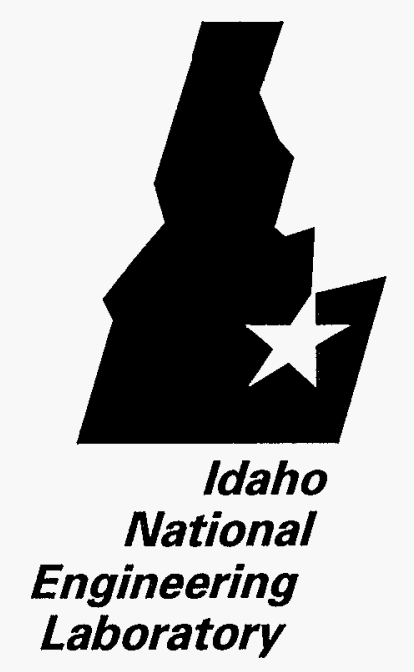

Engineering

Laboratory
INEL-95/0020

Rev. 1

April 14, 1995
Review of Private Sector Treatment, Storage, and Disposal Capacity for Radioactive Waste

\section{Miles Smith}

J. Gordon Harris

Suzanne Moore-Mayne

Roger Mayes

Charles Naretto 
INEL-95/0020

Rev. 1

\title{
Review of Private Sector Treatment, Storage, and Disposal Capacity for Radioactive Waste
}

\author{
Miles Smith \\ J. Gordon Harris \\ Suzanne Moore-Mayne \\ Roger Mayes \\ Charles Naretto
}

Published April 14, 1995

Idaho National Engineering Laboratory

Lockheed Idaho Technologies Company Idaho Falls, Idaho 83415

Prepared for the

U.S. Department of Energy

Assistant Secretary for Environmental Management

Under DOE Idaho Operations Office

Contract DE-AC07-94ID13223 


\section{DISCLAMMER}

Portions of this document may be illegible in electronic image products. Images are produced from the best available original document. 


\begin{abstract}
This report is an update of a report that summarized the current and near-term commercial capacity for the treatment, storage, and disposal of radioactive and mixed waste. This report was written for the Idaho National Engineering Laboratory (INEL) with the objective of updating and expanding the report entitled "Review of Private Sector Treatment, Storage, and Disposal Capacity for Radioactive Waste", (INEL-95/0020, January 1995). The capacity to process radioactively-contaminated protective clothing and/or respirators was added to the list of private sector capabilities to be assessed. Of the 20 companies surveyed in the previous report, 14 responded to the request for additional information, five did not respond, and one asked to be deleted from the survey. One additional company was identified as being capable of performing LLMW treatability studies and six were identified as providers of laundering services for radioactively-contaminated protective clothing and/or respirators.
\end{abstract}

\title{
DISCLAIMER
}

\begin{abstract}
This report was prepared as an account of work sponsored by an agency of the United States Government. Neither the United States Government nor any agency thereof, nor any of their employees, makes any warranty, express or implied, or assumes any legal liability or responsibility for the accuracy, completeness, or usefulness of any information, apparatus, product, or process disclosed, or represents that its use would not infringe privately owned rights. Reference herein to any specific commercial product, process, or service by trade name, trademark, manufacturer, or otherwise does not necessarily constitute or imply its endorsement, recommendation, or favoring by the United States Government or any agency thereof. The views and opinions of authors expressed herein do not necessarily state or reflect those of the United States Government or any agency thereof.
\end{abstract}


ACRONYMS $\quad \ldots \ldots \ldots \ldots \ldots \ldots \ldots \ldots \ldots \ldots \ldots \ldots \ldots \ldots \ldots \ldots \ldots$

INTRODUCTION $\ldots \ldots \ldots \ldots \ldots \ldots \ldots \ldots \ldots \ldots \ldots \ldots \ldots \ldots \ldots \ldots \ldots$

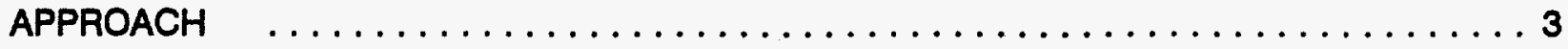

RESULTS OF REVIEW $\ldots \ldots \ldots \ldots \ldots \ldots \ldots \ldots \ldots \ldots \ldots \ldots \ldots \ldots$

LLRW Volume Reduction $\ldots \ldots \ldots \ldots \ldots \ldots \ldots \ldots \ldots \ldots \ldots \ldots \ldots \ldots \ldots \ldots \ldots$

Advanced Recovery Systems, Inc. (ARS) $\ldots \ldots \ldots \ldots \ldots \ldots \ldots \ldots$

Afftrex, Ltd. . . . . . . . . . . . . . . . . . . . . . . 6

ALARON Corporation . . . . . . . . . . . . . . . . . . 6

Allied Technology Group, Inc. (ATG) $\ldots \ldots \ldots \ldots \ldots \ldots \ldots \ldots \ldots \ldots$

American Ecology Corporation (AEC) $\ldots \ldots \ldots \ldots \ldots \ldots \ldots$

Babcock and Wilcox Nuclear Environmental Services, Inc. (B\&W) . . . . . 7

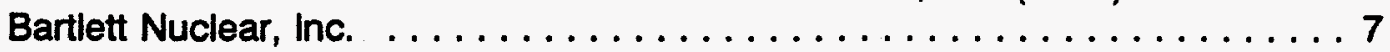

British Nuclear Fuels Limited, Inc. (BNFL) . . . . . . . . . . . . . 7

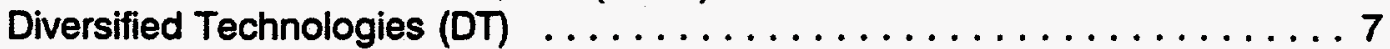

Nuclear Fuel Services, Inc. (NFS) . . . . . . . . . . . . . . . . . 7

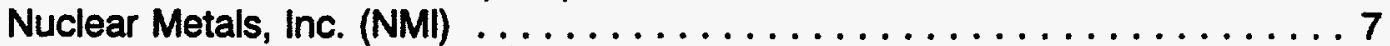

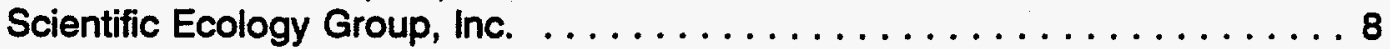

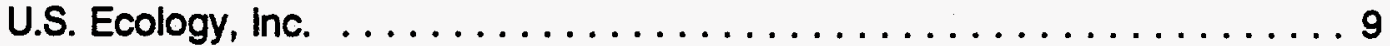

LLMW Treatment . . . . . . . . . . . . . . . . . . . . . . . . . 10

Advanced Recovery Systems, Inc. . . . . . . . . . . . . . . . . 10

American Ecology Corporation . . . . . . . . . . . . . . . . . . . . 10

Babcock and Wilcox Nuclear Environmental Services, Inc. (B\&W) . . . . . 10

British Nuclear Fuels Limited, Inc. . . . . . . . . . . . . . . . . . . . 10

Diversified Scientific Services, Inc. (DSSI) . . . . . . . . . . . . . . . . 10

Diversified Technologies ....................... 11

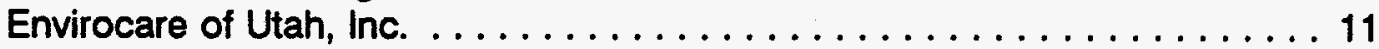

Fluid Tech., Inc. . . . . . . . . . . . . . . . . . . . . . 11

Nuclear Fuel Services, Inc. . . . . . . . . . . . . . . . . . . . . . 11

Nuclear Metals, Inc. . . . . . . . . . . . . . . . . . . . . . 11

RUST Federal Services, Inc. . . . . . . . . . . . . . . . . . . . . . 11

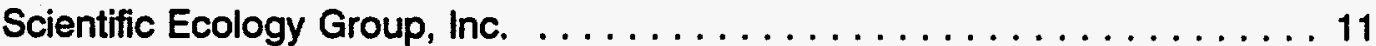

U.S. Ecology . . . . . . . . . . . . . . . . . . . . . . . . . . . . . 12

Low-Level Alpha-Contaminated Mixed Waste $\ldots \ldots \ldots \ldots \ldots \ldots \ldots \ldots$

Advanced Recovery Systems, Inc. . . . . . . . . . . . . . . . . . . 12

Diversified Scientific Services, Inc. . . . . . . . . . . . . . . . . . . 12

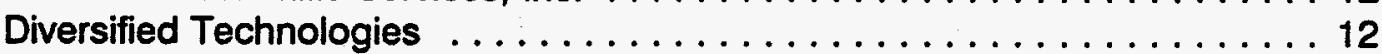

Envirocare of Utah, Inc. . . . . . . . . . . . . . . . . . . . 12

Fluid Tech, Inc. . . . . . . . . . . . . . . . . . . 13

Scientific Ecology Group, Inc. . . . . . . . . . . . . . . . . . 13 
LLMW Treatability Studies $\ldots \ldots \ldots \ldots \ldots \ldots \ldots \ldots \ldots \ldots \ldots \ldots \ldots \ldots$

Advanced Recovery Systems, inc. . . . . . . . . . . . . . 13

Afftrex, Ltd. . . . . . . . . . . . . . . . . . . . . . . 13

ALARON Corporation . . . . . . . . . . . . . . . . . . 13

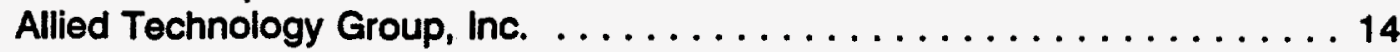

American Ecology Corporation ..................... 14

Babcock and Wilcox Nuclear Environmental Services, Inc. (B\&W) . . . . . 14

COGNIS, Inc. . . . . . . . . . . . . . . . . . . . . . . 14

Diversified Technologies $\ldots \ldots \ldots \ldots \ldots \ldots \ldots \ldots \ldots \ldots \ldots \ldots$

Duke Engineering and Services .................... 14

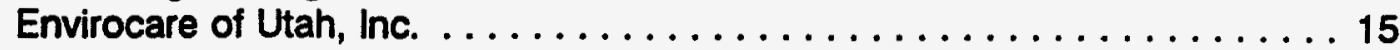

Fluid Tech, Inc. . . . . . . . . . . . . . . . . . . . 15

Hazen Research, Inc. . . . . . . . . . . . . . . . . . . . . 15

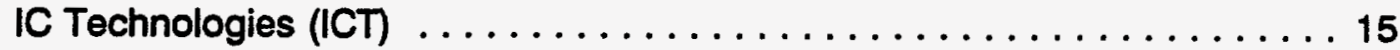

International Technology Corporation $(\mathrm{IT}) \ldots \ldots \ldots \ldots \ldots \ldots \ldots$

Nuclear Fuel Services, Inc. . . . . . . . . . . . . . . . . . . 15

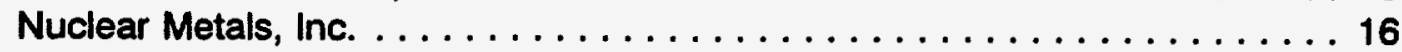

RUST Federal Services, Inc. . . . . . . . . . . . . . . . . 16

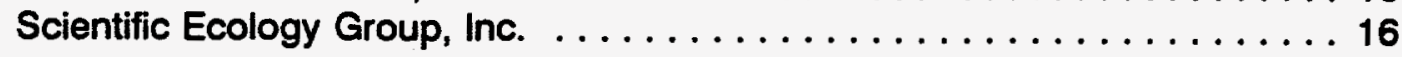

LLRW Decontamination and Recycling Services $\ldots \ldots \ldots \ldots \ldots \ldots$

Advanced Recovery Systems, Inc. . . . . . . . . . . . . . 16

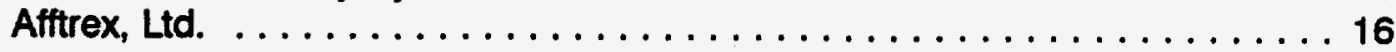

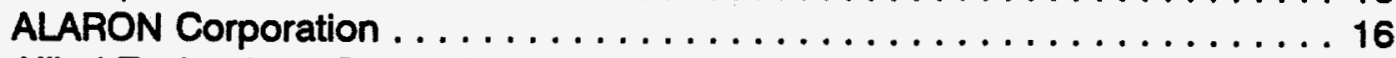

Allied Technology Group, inc. . . . . . . . . . . . . . . . . 17

American Ecology Corporation . . . . . . . . . . . . . . . . 17

Babcock and Wilcox Nuclear Environmental Services, Inc. . . . . . . . . . 17

Bartlett Nuclear, Inc. . . . . . . . . . . . . . . . . . . . . 17

British Nuclear Fuels Limited, Inc. . . . . . . . . . . . . . . . 17

Diversified Scientific Services, Inc. . . . . . . . . . . . . . . . 18

Interstate Nuclear Services Corporation (INS) $\ldots \ldots \ldots \ldots \ldots \ldots \ldots$

Non-Destructive Cleaning, Inc. (NDC) . . . . . . . . . . . . . . 18

Nuclear Fuel Services, Inc. . . . . . . . . . . . . . . . . . . . 18

Nuclear Metals, Inc. (NMI) . . . . . . . . . . . . . . . . 18

RUST Federal Services, Inc. . . . . . . . . . . . . . . . . 18

Scientific Ecology Group, Inc. . . . . . . . . . . . . . . . . 18

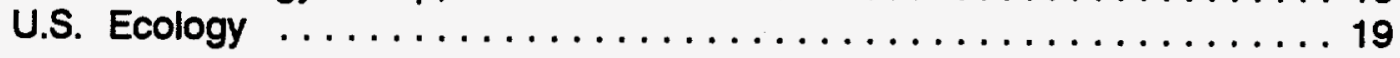

Storage and Disposal of LLMW ... . . . . . . . . . . . . . 19

Envirocare of Utah, Inc. . . . . . . . . . . . . . . . 19

Nuclear Fuel Services, inc. . . . . . . . . . . . . . . . . . . 19

Nuclear Metals, Inc. . . . . . . . . . . . . . . . . . . . . 19 


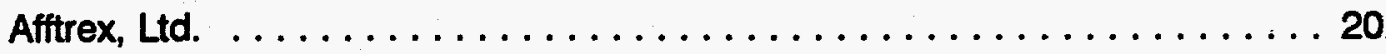

Bartlett Nuclear, Inc. ............................. 20

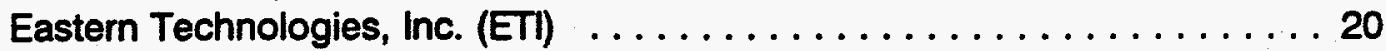

Interstate Nuclear Services Corporation .................. 20

Nuclear Fuel Services, Inc. ......................... 21

Octagon/Power Systems Energy Services, Inc. (PSESI) . . . . . . . 21

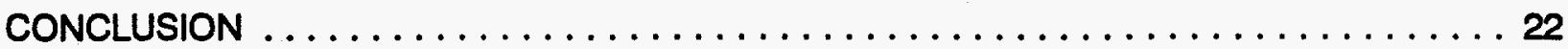

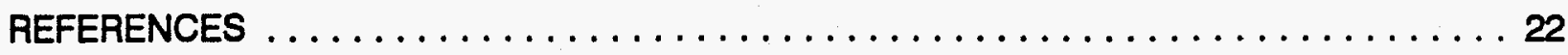

APPENDIX A-Vendor Contact Telefax $\ldots \ldots \ldots \ldots \ldots \ldots \ldots \ldots \ldots \ldots \ldots \ldots \ldots \ldots \ldots \ldots$

APPENDIX B-Vendor Contact Follow-Up $\ldots \ldots \ldots \ldots \ldots \ldots \ldots \ldots \ldots \ldots \ldots \ldots \ldots \ldots$

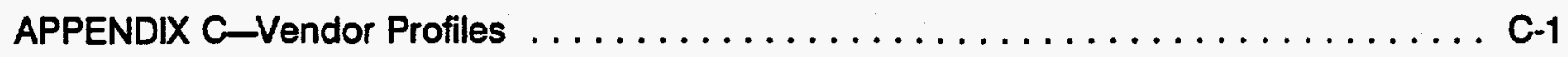

APPENDIX D-Vendor Radioactive Material License Limit Profile .............. D-1

TABLES

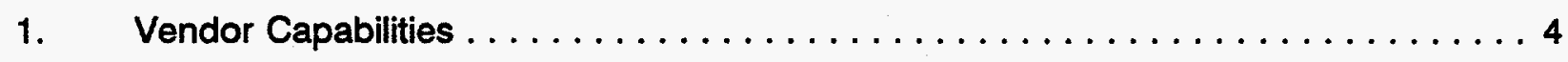




\section{ACRONYMS}

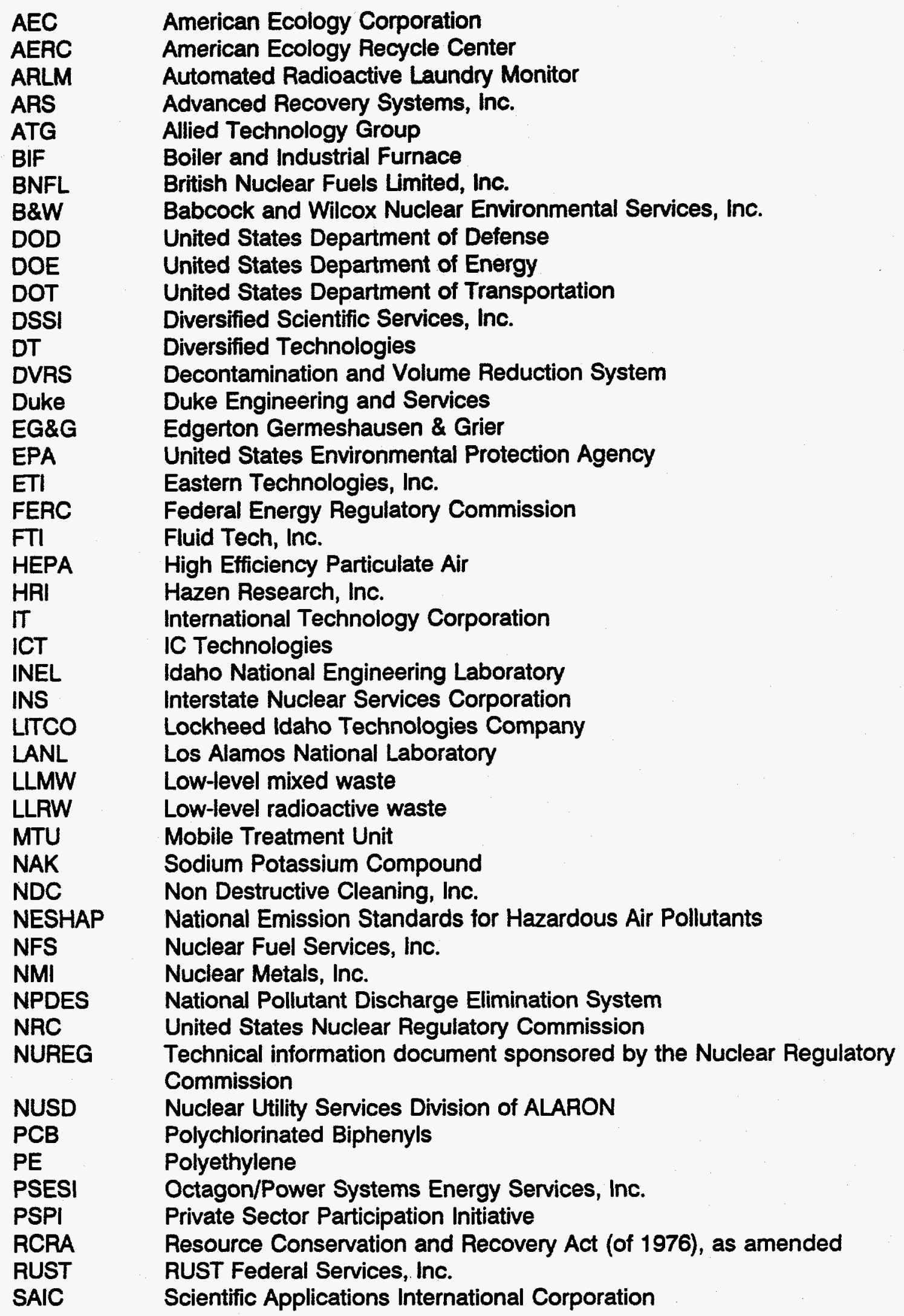


Scientific Ecology Group, Inc.

TDC

\section{Sandia National Laboratories}

TSCA

TSD

USE

VES

Tennessee Department of Conservation

Transuranic

Toxic Substances Control Act

Treatment, storage, and disposal

U.S. Ecology

WAMAC

Vinyl Ester Styrene

Waste Monitoring and Compaction Facility 
BEVIEW OF PRIVATE SECTOR TREATMENT, STORAGE, AND DISPOSAL CAPACTYY FOR RADIOACTIVE WASTE

Revision 1.0, April 14, 1995

\section{INTRODUCTION}

Private sector capacity for treatment, storage, and disposal of various categories of radioactive waste has been researched and reviewed for the Idaho National Engineering Laboratory (INEL) now operated by Lockheed Idaho Technologies Company (LITCO). Of 20 companies surveyed for the 1994 report, one requested to be removed from the survey, and a new category for laundering of radioactively-contaminated protective equipment resulted in the identification of six new companies that are included in this 1995 report. Additionally, one new company for the original categories was identified and responded to this year's survey.

The survey of private sector capacity was limited to companies currently capable of treatment, storage, and/or disposal of low-level radioactive waste (LLRW) and low-level mixed waste (LLMW), and companies expected to be permitted for such within the next five years. Private sector vendors were reviewed for treatment, storage, and disposal capacity and the ability to perform treatability studies for the following categories:

- $\quad$ LLRW volume reduction

- $\quad$ LLMW treatment

- Low-level alpha-contaminated mixed waste

- $\quad$ LLMW treatability studies

- $\quad$ LLRW decontamination/recycling (including contaminated metals)

- $\quad$ LLMW storage and disposal

- Laundering of radioactively-contaminated laundry and/or respirators

Sources of existing information and new information were used to compile a list of potential vendors. Existing sources of information included letter reports previously prepared by EG\&G Idaho (a former management and operating contractor at the INEL) for the Private Sector Participation Initiative (PSPI), Garrison and Mousseau (1993), and Piper and Mousseau (1993). Additional sources of information were the Nuclear News: Buyers Guide (American Nuclear Society 1995) and the World Directory of RadWaste Managers (American Nuclear Society 1992), which contain listings of vendors that provide waste management services. Companies were identified as candidate vendors from the compiled list according to the type of waste management services advertised (i.e., mixed waste and/or low-level waste), and to some extent, professional knowledge of the companies.

For the 1994 report, the potential vendors were first contacted by phone to verity names, addresses, and telephone and telefax numbers, and to screen out companies that do not perform any of the required services. Questionnaires were then telefaxed to the qualified vendors. The questionnaire was used to determine the extent of each vendor's current and near-term low-level and mixed waste capabilities. Responses to the questionnaire were used to categorize each vendor according to the seven categories listed in the introduction of that report. The 1994 report did not survey laundering capabilities. Finally, copies of relevant licenses, permits, and additional literature were requested from each of the vendors.

The level of detail about each vendor's capabilities presented in this report varies as a 
result of the completeness of the information provided by individual vendors. In many cases vendors provided only limited responses to the questionnaire and did not follow-up with more detailed brochures or company literature as requested. However, others provided a great deal of information on licenses, treatment technologies, and capacities which is summarized herein. 


\section{APPROACH}

The vendors identified in the initial 1994 vendor survey report were contacted by phone to reverify names, addresses, and telephone and telefax numbers. Company profiles and capability descriptions from the 1994 report were telefaxed to each vendor beginning March 17, 1995 (see Appendix B). Each vendor was asked to review the capability description and company profile, make any necessary revisions on the telefax, and return the information as soon as possible. Vendors that had not responded by March 21, 1995 were contacted to facilitate the request for current information. During this period, Applied Radiological Control, Inc. asked to be removed from this vendor survey. Additional telephone or telefax communications took place (until April 13,1995) with some vendors to clarify information.

Both the 1994 and 1995 editions of the Nuclear News Buyers Guide were used to identify vendors associated with the new category for identifying laundering services and equipment. Twenty vendors were identified from these sources and from references within the laundering services field. The vendors were contacted by phone and questioned concerning the types of services performed by their company. If any positive answers were received within the seven technical areas identified for the report, a telefax was sent to the vendor's point of contact (See Appendix A). If the vendor provided laundering services, follow-up information was requested (e.g., brochures, statement of qualifications, flyers). The information provided by the vendors was used to develop the capability descriptions and company profiles. This information was telefaxed to the vendor for comment and concurrence (See Appendix B). Responses from the vendors were incorporated into the narratives, which are included in this report in Appendix $C$ and in the section on laundering of radioactively-contaminated laundry.

In addition to the sources mentioned above, names of other potential survey participants were obtained from INEL Report-94/002, dated October 1994, which describes a vendor forum held at the INEL in August 1994 to identify private sector capabilities to treat LLRW and LLMW.

\section{RESULTS OF REVIEW}

Of 20 companies surveyed last year, Applied Radiological Control, Inc. requested to be removed from the survey, 14 companies responded to requests for additional information, and five companies did not respond. Additionally, one new company, COGNIS, Inc., was identified for providing services from the original seven technical categories.

Twenty vendors were identified from sources and references within the laundering services field. Six vendors were identified as providing services for laundering of radioactively-contaminated laundry and/or respirators. Their capability descriptions and profiles are included herein. Table 1 lists each of the respondents and identifies the category of services provided. 
Table 1. Vendor Capabilities

\begin{tabular}{|c|c|c|c|c|c|c|c|}
\hline Vendor & $\begin{array}{l}\text { LLRW Volume } \\
\text { Reduction }\end{array}$ & LLMW Treatment & $\begin{array}{c}\text { Alpha- } \\
\text { Contaminated } \\
\text { LLMW Treatment }\end{array}$ & $\begin{array}{c}\text { LLMW Treatability } \\
\text { Studies }\end{array}$ & $\begin{array}{l}\text { LLRW } \\
\text { Decontamination } \\
\text { and Rocycling }\end{array}$ & $\begin{array}{l}\text { LLMW Storage } \\
\text { and Disposal }\end{array}$ & $\begin{array}{l}\text { Laundering of } \\
\text { Contaminated } \\
\text { Laundry }\end{array}$ \\
\hline AEC & $x$ & $x$ & - & $x$ & $x$ & - & - \\
\hline Afftrex & $x$ & - & - & $x$ & $x$ & - & $x$ \\
\hline ARS & $x$ & 1 & 1 & $x$ & $x$ & - & - \\
\hline ALARON & $x$ & - & - & $x$ & $x$ & - & - \\
\hline ATG & $x$ & - & - & $x$ & $x$ & - & - \\
\hline Bartlett & $x$ & - & - & - & $x$ & - & $x$ \\
\hline B\&W & 2 & 2 & - & 2 & 2 & - & - \\
\hline BNFL & $x$ & $x$ & - & - & $x$ & - & - \\
\hline COGNIS & - & - & - & $x$ & - & - & - \\
\hline DSSI & - & $x$ & $x$ & - & $x$ & - & - \\
\hline DT & $x$ & $x$ & $x$ & $x$ & - & - & - \\
\hline Duke & - & - & - & $x$ & - & - & - \\
\hline Envirocare & - & 3 & $x$ & $x$ & - & $x$ & - \\
\hline ETI & - & - & - & - & - & - & $x$ \\
\hline FTI & - & $x$ & $x$ & $x$ & - & - & - \\
\hline HRI & - & - & - & $x$ & - & - & - \\
\hline ICT & - & - & - & $x$ & - & - & - \\
\hline INS & - & - & - & - & $x$ & - & $x$ \\
\hline IT & - & - & - & $x$ & - & - & - \\
\hline NDC & - & - & - & - & $x$ & - & - \\
\hline NFS & $x$ & $x$ & - & $x$ & $x$ & $x$ & $x$ \\
\hline NMI & $\mathbf{x}$ & $\mathbf{x}$ & - & $x$ & $x$ & $x$ & - \\
\hline
\end{tabular}


Table 1. Vendor Capabilities (Cont.)

\begin{tabular}{|c|c|c|c|c|c|c|c|}
\hline Vendor & $\begin{array}{l}\text { LLRW Volume } \\
\text { Reduction }\end{array}$ & LLMW Treatment & $\begin{array}{c}\text { Alpha- } \\
\text { Contaminated } \\
\text { LLMW Treatment }\end{array}$ & $\begin{array}{c}\text { LLMW Treatability } \\
\text { Studies }\end{array}$ & $\begin{array}{l}\text { LLRW } \\
\text { Decontamination } \\
\text { and Recycling }\end{array}$ & $\begin{array}{l}\text { LLMW Storage } \\
\text { and Disposal }\end{array}$ & $\begin{array}{c}\text { Laundering of } \\
\text { Conteminated } \\
\text { Laundry }\end{array}$ \\
\hline PSESI & - & - & - & - & - & - & $x$ \\
\hline RUST & - & $x$ & - & $x$ & $x$ & $x$ & - \\
\hline SEG & $x$ & $x$ & $x$ & $x$ & $x$ & - & - \\
\hline USE & $x$ & 4 & - & - & $x$ & - & - \\
\hline
\end{tabular}

1. Pilot-scale treatment only available at this time.

2. For waste generated by B\&W's Naval Nuclear Fuel Division only.

3. Stabilization only.

4. Institutional clients, hospitals, and universities only. 


\section{LLRW Volume Reduction}

Advanced Recovery Systems, inc. (ARS): ARS has successfully developed a system to reduce the volume of low-level radioactive waste solutions. Systems were successfully tested and implemented to extract cesium and cobalt from high nitrate-bearing waste solutions. A "clean" sodium nitrate salt stream is synthesized and meets specifications for chemical process industry feed.

Afftrex, Ltd.: Afftrex performs volume reduction treatment of LLRW at several DOE sites. The company applies the processes of segregation, sizing, destructive and nondestructive disassembly for improved survey accessibility, and decontamination by mechanical and non-hazardous chemicals.

ALARON Corporation: ALARON operates a fixed-base service facility in Wampum, Pennsylvania under NRC licenses that allow the possession of radioactive isotopes with atomic numbers 3 through 96. ALARON can provide supercompaction of dry, active LLRW at a capacity of $5,700 \mathrm{~m}^{3}\left(200,000 \mathrm{ft}^{3}\right)$ annually. ALARON is also capable of reducing the volume of $3400 \mathrm{~m}^{3}\left(120,000 \mathrm{tt}^{3}\right)$ annually of radioactively contaminated metals by segmentation and dense packaging. Its NRC License No. 37-20826-01 expired in 1990, but they currently operate under an indefinite extension. ALARON's other NRC License, No. 37-20826-02, expired September 30, 1994, but as of the 1994 Survey, was expected to be extended or combined with License No. 37-20826-01 (ALARON did not provide any additional information in 1995).

Allied Technology Group, Inc. (ATG): Although ATG did not return a completed questionnaire in 1994, it sent a brochure that indicated the company operates a fully licensed supercompactor facility in Richland, Washington providing volume reduction services. ATG has the resources to provide supercompaction services at the customer's site. ATG has designed their own mobile supercompactor with unique features. The supercompactor has a horizontal ram for low vertical profile. It is capable of compacting 75 drums per shift operated by two technicians. Costs per drum are $\$ 50$ to $\$ 75$, commercial rate, depending upon contents.

American Ecology Corporation (AEC): American Ecology, formerly Quadrex, operates a facility in Oak Ridge, Tennessee that is currently licensed to perform volume reduction treatment on approximately $28,000 \mathrm{~m}^{3}\left(1.0 E+06 \mathrm{ft}^{3}\right)$ of LLRW annually. The facility, the American Ecology Recycling Center (AERC), operates under a radioactive material license from the State of Tennessee (License No. R-01037-J95) that expires October 31, 1995. AEC will begin the renewal process during the summer of 1995 and expects state approval but with some contingencies. AEC's compactables processing system uses a combination of sorting, pre-surveying, decontamination, and supercompaction to achieve high volume reduction percentages (85 percent or better). Wastes introduced for volume reduction are initially unpacked, sorted, and pre-surveyed. Material sufficiently low in activity to suggest it is not contaminated is removed from the waste stream and sent to the survey department where it is surveyed through an automated waste monitor. Material that meets the recycle center's licensed release criteria is released for disposal in a commercial landfill. The material that does not pass inspection is pre-compacted in AEC specially-designed baling equipment, which results in orthogonal compaction. This technique applies force along all three axes instead of just one. Finally, the waste volume is further reduced in a $2.0 E+06 \mathrm{~kg}(2,200-$ ton $)$ 
supercompactor. The orthogonal compaction technique results in an additional 10 to 15-percent volume reduction over standard uni-direction drum compaction followed by supercompaction. AEC also offers an incineration option for portions of bulk waste sent to the facility. Although AEC does not operate an incinerator, incinerable waste can be separated from nonincinerable waste and shipped to an incinerator. The facility may accept waste containing mixed activation and mixed fission products with atomic numbers from 3 to 83 , source material such as natural or depleted uranium, small quantities of special nuclear material and transuranics, and sealed sources.

Babcock and Wilcox Nuclear Environmental Services, Inc. (B\&W): B\&W capabilities and facilities support the waste management needs of the Babcock and Wilcox company's Naval Nuclear Fuel Division. B\&W builds from this base of experience and offers one-stop low-level radioactive and low-level mixed waste remediation services to industry and government clients. B\&W maintains a fully equipped research and development center at its Lynchburg Technology Center in Lynchburg, Virginia. B\&W has high-limit, source, byproduct, and special nuclear material licenses. B\&W utilizes a super compaction method to achieve volume reduction treatment of LLRW. Treatment capacity information was not provided.

Bartlett Nuclear, Inc: Bartlett has a Mobile Waste MonitorNolume Reduction System, which is a self-contained trailer designed to monitor all dry waste leaving a site. Clean waste is shredded into one-half inch pieces that are disposed of as clean trash. The waste monitor will detect $\mathbf{5 0 0 0} \mathrm{dpm}$ above background levels assuming uniform distribution per $\mathbf{5 0}$ pound bag of waste. This measurement is at the 95 percent probability of detection.

British Nuclear Fuels Limited, Inc. (BNFL): BNFL is currently developing the Waste Monitoring and Compaction Facility (WAMAC) at the Sellafield LLRW disposal site in Sellafield, United Kingdom. At the WAMAC, drums and boxes will be compacted using a 5,000 metric ton (5,512 ton) hydraulic press. Once compacted, the waste will be packaged and shipped to the Drigg Grouting Facility where the void spaces will be filled with grout. The waste is then disposed in vaults at the Sellafield LLRW Disposal Facility, also operated by BNFL. The WAMAC facility is scheduled to become operational in early 1995. Applicable regulatory licensing information for these overseas facilities was not provided, nor was information on facilities in this country.

Diversified Technologies (DT): DT has a Mobile Treatment Unit (MTU) for sludge dewatering, drying, volume reduction and polymer solidification for treating $1,000 \mathrm{lbs} / \mathrm{hr}$ of solids. DT offers the use of thermosetting polymers for in-situ solidification of wastes and reverse osmosis processes for volume reduction of liquid wastes. DT will offer on-site waste treatment using self-contained, skid-mounted equipment.

Nuclear Fuel Services, Inc. (NFS): NFS has created the Decontamination and Volume Reduction System (DVRS). DVRS is a waste management tool which is used in decontamination and decommissioning projects. A disposable waste volume reduction ratio of approximately 5:1 has been achieved.

Nuclear Metals, Inc.: NMI claims to provide reduction services for LLRW but information on the company's capabilities was not included in their response to this survey. 
Scientific Ecology Group. Inc. (SEG): SEG has several methods of volume reduction for LLRW. SEG currently operates an incinerator licensed for radioactive waste in Oak Ridge, Tennessee, which provides a volume reduction ratio as high as 200:1. SEG has installed another incinerator that will be fully operational by the summer of 1995. This incinerator will be dedicated to processing DOE wastes. Waste accepted for the SEG incinerators must be less than $200 \mathrm{mR} / \mathrm{hr}$. Processing of INEL dry active waste by SEG in 1994 achieved a volume reduction of $320: 1$.

The following materials have been approved for SEG incineration:

- Polycarbonate

- Polypropylene

- High Density Polyethylene

- Nitrile or Nitrile Rubber

- Polyethylene

- Lightly Vulcanized Rubber with <1000 ppm Sulfur

- Transparent Thermoplastic

- Ultra-High Molecular Weight Polyethylene

- Oils

- Acrylonitrile Butadiene Styrene

- Modified Phenylene Oxide

- Sewage Sludge

- Ethylene Glycol (Anti-Freeze)

- Oil Based Wiping Cloth

- 100\% Cotton Cloth

- Natural Rubber
- Latex

- Polyester

- Nyion

- Paper

- Polystyrene

- Spun, Bonded Polyolefin

- Styrofoam

- Urethane

- Hemp Rope

- Polyacrylate

- Graphite

- Wood

- Leather

- Resin

- Charcoal

- Aqueous Liquids

- 100\% Cotton Cloth-Flame Resistant

After incineration, the bottom ash is packaged in appropriate burial/storage containers. Ash samples will be taken and tested to ensure compliance with Resource Conservation and Recovery Act (RCRA) requirements. Ashes are then compacted using the SEG

ULTRACompactorm to maximize volume reduction and provide a more stable waste form. If ash does not pass RCRA requirements for disposal, SEG will stabilize the bottom ash to meet those requirements. Radioactively-contaminated oil is also burned in the SEG incinerator achieving a 100-percent volume reduction. The oil's activity level must be less than $200 \mathrm{mR} / \mathrm{hr}$. SEG has successfully incinerated over 3 million cubic feet of contaminated materials since beginning incineration services in 1990. Fly ash becomes the property of SEG.

The SEG Metal Processing Facility is capable of processing approximately $12 \mathrm{E}+06 \mathrm{~kg}$ per year (13,000 tons per year) of slightly contaminated or activated metal for use in DOE high energy physics programs, in the manufacture of containers for radioactive waste storage or burial, and for unrestricted release. SEG has released the following quantities of metals for unrestricted use: $1993-215,270 \mathrm{~kg}(474,456 \mathrm{lb}$.); $1994-284,470 \mathrm{~kg}$ $(627,145 \mathrm{lb}$.$) ; and for the first two months of 1995$ - $116,400 \mathrm{~kg}(256,649 \mathrm{lb}$.$) . SEG's facility,$ 
located in Oak Ridge, TN, houses a 20-ton, 7,200-kilowatt induction furnace that can melt carbon and stainless steel, copper, brass, and lead.

SEG operates a super compactor (called the SEG ULTRACompactor ${ }^{\text {tm }}$ ) that crushes drums and boxes with a force of $4.5 E+06 \mathrm{~kg}(1.0 \mathrm{E}+07 \mathrm{lb})$ achieving a volume reduction ratio of 10:1. The ULTRACompactor ${ }^{\mathrm{tm}}$ processes over 70,000 cubic feet of waste each month. Typical wastes processed include non-incinerable paper, plastic, wood, asbestos, and small metal items. The UltraCompactor ${ }^{\text {tm }}$ is the largest commercial waste compactor available in the world for processing dry active waste. It has the unique ability to process 52-gallon drums, 55-gallon drums and 4'x3'x3' metal boxes. The ability to compact boxed materials gives SEG the capability of compacting materials/items previously considered noncompactable (i.e., motors, pumps, piping, valves, and conduits).

SEG typically accepts waste for compaction up to an external dose rate of $5 \mathrm{R} / \mathrm{hr}$ on contact, but can handle material with higher dose rates on a case-by-case basis. All wastes in excess of $200 \mathrm{mR} / \mathrm{hr}$ must be identified prior to shipment and all waste exceeding $1 \mathrm{R} / \mathrm{hr}$ must be packaged in a drum to minimize direct handling. Asbestos can also be compacted in scheduled campaigns. SEG complements its ULTRACompactor ${ }^{\text {tm }}$ with the TRU Press, a compactor devoted to reducing the volume of transuranic waste. Quantities of transuranics are kept within the limits specified in SEG's radioactive materials license (see Appendix D). A mobile super compactor, fully contained with all the essential elements for compacting drums, is also available to customers for on-site operation.

The SEG vacuum compression dewatering of spent powdered filter and ion-exchange media provides in-container volume reduction. A compressive force of $113,000 \mathrm{~kg}$ $(250,000 \mathrm{lb})$ surrounds the waste form, closing interstitial spaces and squeezing water from the waste solids. The final processing step is a high vacuum compression cycle to ensure there is no free water in the waste.

SEG accepts a large number of radionuclides including mixed fission products and transuranic waste contaminated to levels below $10 \mathrm{nCi} / \mathrm{g}$. All facilities operated by SEG in the Oak Ridge area hold current licenses from the State of Tennessee. The combined limit for radionuclides is $800 \mathrm{Ci}$ with additional limitations of $700 \mathrm{~g}$ for ${ }^{235} \mathrm{U}, 400 \mathrm{~g}$ for ${ }^{238} \mathrm{U}$, and $400 \mathrm{~g}$ for all plutonium isotopes.

SEG has completed a bench-scale testing program to process radioactively contaminated resin using a molten metal solvent system. The catalytic extraction processing technology uses a molten metal bath to convert waste into raw materials. The process breaks molecular bonds, converting compounds into elements, and destroys hazardous and toxic materials in mixed waste. It captures radionuclides in a stable, nonleachable matrix for final form disposal. The process also decontaminates gases and metals for potential reuse/recycle. The process achieves a volume reduction of 30:1.

U.S. Ecology: U.S. Ecology provides volume reduction services for LLRW. This service is limited to institutional clients, hospitals, and universities. No further information was provided in their response to this survey. 


\section{LLMW Treatment}

Advanced Recovery Systems, Inc.: ARS has performed pilot-scale operations to remove mercury from LLMW, changing the classification to LLRW. The company operates a development laboratory in Erwin, Tennessee. A patent re-application has been filed for treatment of mercury-bearing wastes using chemical reagent technology. This application can treat a variety of waste streams.

American Ecology Corporation: According to their questionnaire response, AEC is not currently capable of treating mixed waste, but has applied for a RCRA permit to treat small quantities of mixed waste via thermal treatment.

Babcock and Wilcox Nuclear Environmental Services, Inc. (B\&W): B\&W capabilities and facilities are currently reserved solely for the support of waste management needs of the Babcock and Wilcox company's Naval Nuclear Fuel Division. B\&W maintains a fully equipped research and development center at its Lynchburg Technology Center in Lynchburg, Virginia. $B \& W$ has high-limit, source, by-product, and special nuclear material licenses. B\&W uses the following methods to treat LLMW: neutralization, micro-filtration, microwave separation, compaction, stabilization/solidification, distillation, and delisting. Treatment capacity information was not provided.

British Nuclear Fuels Limited, Inc.: BNFL has facilities operating in the United Kingdom that vitrify and grout liquid radioactive waste and encapsulate solid radioactive waste. BNFL can also treat soil contaminated with heavy metals at waste-generating sites. BNFL, in cooperation with Raytheon Engineers and Constructors, has an interest in providing turnkey treatment, transportation, and packaging for INEL mixed wastes.

Diversified Scientific Services, Inc. (DSSI): DSSI operates a fully licensed LLMW processing facility in Kingston, Tennessee that is capable of burning radioactivelycontaminated solvents as waste fuel for power production. The solvent processing facility employs an industrial boiler to combust solvents to generate electricity for the facility's inhouse use and for sale to electric companies. The waste fuel boiler system is equipped with a dual fuel burner designed to use propane and waste as fuel to maintain boiler operating conditions within regulatory and permit requirements. Propane is used to bring the steam generator up to the required operating temperature and pressure before introducing the waste fuel into the burner. DSSI typically receives wastes in five gallon containers to 55 gallon drums, which are segregated by compatibility and BTU value. The wastes are then decanted into one of three 10,000 gallon tanks that feed into boilers. DSSI currently is expanding its tank farm to eight 10,000 gallon tanks, which should be completed by May 1995.

DSSI's radiological license allows it to receive solvents containing over 2,000 isotopes including mixed waste containing special nuclear material from Department of Energy (DOE) and Department of Defense (DOD) facilities. DSSI can accept an extensive list of F-, D-, and U-listed hazardous wastes. The facility can burn approximately $4.2 E+06 \mathrm{~L}(1.1 \mathrm{E}+06 \mathrm{gal})$ of mixed waste solvents per year. DSSI requires a fuel blending analysis of a generator's waste prior to acceptance. Waste generators can provide this information or utilize DSSI's analytical laboratory capabilities, which support their own waste blending activities. DSSI's analytical laboratory is not equipped to perform waste characterization. Stabilized ash from the processing facility is sent to Envirocare of Utah, Inc. 
Diversified Technologies: Diversified Technologies (DT) does not currently have any licensed facilities to treat mixed waste. However, the company has applied for an NRC license and has a permit to conduct treatability studies, specializing in solidification of LLRW and LLMW, at its facility in Knoxville, Tennessee. The company expects approval of the NRC license application by May 1995. The facility will use a Vinyl Ester Resin In-Situ (VERI) system, Vinyl Ester Styrene (VES), Polyethylene (PE) and Sulphur Polymer to solidify incinerator ash, powders, sludges, and filter media to form a more stable waste form than cement or bitumen solidification. The facility can also dewater waste using a high velocity vacuum. In addition, DT will also be able to perform on-site solidification services using selfcontained skid-mounted units.

Envirocare of Utah, Inc.: Envirocare operates a licensed LLRW and LLMW treatment and disposal facility in Utah. The treatment capability of the facility is limited to chemical stabilization of concentration-based mixed waste to meet land disposal restrictions. A RCRA Part B modification addressing lead encapsulation has been submitted to the State for review. Approval is expected in September 1995. Specific details on its treatment capabilities were not provided.

Fluid Tech, Inc.: Fluid Tech has the treatment reagents, equipment, and trained personnel to solidify/stabilize LLMW for generators at the generator's site.

Nuclear Fuel Services, Inc.: The company has development and engineering facilities for researching and evaluating remediation processes for treating radioactive and mixed wastes including $\mathrm{U}, \mathrm{Pu}$, and Th, minimizing waste, and resource recovery .

Nuclear Metals, Inc.: NMI currently operates under a radioactive materials license and a RCRA permit. NMI uses the Sludgemaster process to solidify LLMW oils. Detailed information on the Sludgemaster process was not provided.

RUST Federal Services, Inc.: Although RUST does not currently operate permitted LLMW treatment facilities, it expressed a willingness to invest in treatment facilities that can offer whatever capacity DOE and its management contractors can commit to. The company would be willing to provide both fixed and transportable treatment systems once DOE defines the market demand. RUST uses technologies consisting of thermal treatment of volatile organic mixed waste, leachate treatment of mixed waste, bioremediation, soil washing, dechlorination of polychlorinated biphenyls (PCB), and chemical stabilization and solidification. RUST indicated that it has used these technologies to provide full-scale treatment systems at some waste generating sites.

Scientific Ecology Group, Inc.: SEG has vitrification technology for organic, wet, or aggregate wastes. The vitrification produces a waste form that needs no reprocessing. SEG has a mobile vitrifier. It is an electric joule-heated melter equipped with complete off-gas treatment and process monitoring systems; it provides flexible operating characteristics for a wide range of waste feeds.

SEG has a patented synthetica detoxifier system, not yet permitted, that performs a very high-temperature steam reforming process similar to coal gasification, but for safety purposes it operates without oxygen at atmospheric pressure and it does not employ incinerator technology. Essentially, the steam reforming process breaks down all organic wastes into carbon dioxide and steam. Applications for this process are on waste solvents, 
aqueous wastes, paint sludges, laboratory organics. SEG will be testing this technolo stes, degreasing sludges, and off-spec mixed at the Tennessee site during the spring of 1995.

SEG has applied for a RCRA Part B ermit to employ these technologies and expects approval during 1995. SEG is currently capuble of performing mixed waste treatability studies in its mixed waste laboratory in Oak Ridge, TN. SEG can conduct bench and pilot-scale treatability studies on LLMW at its laboratories in Oak Ridge, Tennessee, and Pittsburgh, Pennsylvania. Stabilization and vitrification testing have been successfully performed on a variety of LLMWs. SEG is interested in developing new treatment methods for LLMW.

Finally, SEG is capable of solidifying low-level mixed waste onsite at clients' facilities. It is currently operating this process at Oak Ridge National Laboratory. Wastes requiring stabilization are solidified in high-integrity containers, while wastes not requiring stabilization are solidified in steel liners.

SEG currently operates under a radioactive materials license and an interim status RCRA permit. SEG expects to receive a RCRA Part B permit to treat, store, or dispose of LLMW in 1995. SEG decontaminates and recycles LLRW metals. SEG states that it has the largest, most technologically advanced metal decontamination facility with the only dedicated foundry for radioactive metals in the United States. Most metals are decontaminated via highpressure water, steel shot, or glass bead blasting. Metals, including steel, stainless steel, copper, brass, and lead are routinely released by SEG. SEG also melts LLRW metal into blocks used for shielding at DOE facilities. Stainless steel, carbon steel, and aluminum are commonly processed in this fashion. Over 15 million pounds of contaminated metals were processed for re-use or release in 1993.

U.S. Ecology: U.S. Ecology indicated that their LLMW capability is limited to treating scintillation vials.

\section{Low-Level Alpha-Contaminated Mixed Waste}

Advanced Recovery Systems, Inc.: ARS holds licenses and permits that allow receipt of uranium and plutonium-contaminated mixed wastes to perform pilot-scale treatment. Based upon the pilot process, a full-scale system can be designed.

Diversified Scientific Services, Inc.: DSSI is capable of accepting mixed waste solvents containing special nuclear material at their LLMW processing facility in Kingston, Tennessee. DSSI's license enables the facility to accept special nuclear and source material from DOE and DOD facilities and over 2,000 other radionuclides. The radionuclides and concentration limits are stated in the radioactive materials license and the facility's waste acceptance criteria. All permits and licenses are current except the air permit, which is being reviewed by the State.

Diversified Technologies: Although the company claimed a capability for treating lowlevel alpha-contaminated mixed waste, no specific information concerning the company's capabilities was included in their response to this survey.

Envirocare of Utah, Inc.: Envirocare is currently licensed to accept LLRW and LLMW contaminated with alpha-emitting isotopes, including transuranics, with concentrations less 
than $100 \mathrm{nCi} / \mathrm{g}$. The isotopic acceptance limits defined in Envirocare's Radioactive Materials License (RML) of concern to the INEL, are ${ }^{241} \mathrm{Am}, 0.23 \mathrm{nCi} / \mathrm{g} ;{ }^{238} \mathrm{Pu}, 10.0 \mathrm{nCi} / \mathrm{g} ;{ }^{239} \mathrm{Pu}$, $9.9 \mathrm{nCi} / \mathrm{g} ;$ and ${ }^{240} \mathrm{Pu}, 10.0 \mathrm{nCi} / \mathrm{g}$. Exact limits for each isotope are defined in the facility's radioactive materials license, which expires February 28, 1996.

Fluid Tech, Inc.: Although the company claimed a capability for treating low-level alpha-contaminated mixed waste, no specific information concerning the company's capabilities was included in their response to this survey.

Scientific Ecology Group, Inc. (SEG): SEG currently operates a TRU-waste compactor, specially equipped to address the hazards of processing TRU waste. The TRU Press is specifically constructed and licensed for the special processing containment requirements of transuranic-contaminated (alpha-emitting) dry active waste. The SEG TRU Press is said to deliver the highest volume reduction ratios possible in the world for compacting TRU waste. SEG is the only commercial company in the United States to supercompact TRU waste. A 520-ton hydraulic press provides the compaction force to compress waste packaged in 43-, 52-, and 55-gallon drums or 79- and 89-gallon leak-tight overpack containers. The TRU Press is computer-controlled in the same manner as the ULTRACompactor ${ }^{\mathrm{m}}$, and incorporates many of the same features to ensure safe operation. The entire compactor unit is contained to preclude the spread of contamination, and negative pressure is maintained on the containment.

\section{LLMW Treatability Studies}

Advanced Recovery Systems, Inc.: ARS conducts mixed waste treatability studies for commercial and government clients. ARS has treatability and development laboratories in Erwin, Tennessee that are licensed by the State of Tennessee and the NRC to accept hazardous and radioactive materials, respectively. The laboratories are capable of accepting up to $10,000 \mathrm{~kg}(22,000 \mathrm{lb})$ of mixed waste pursuant to the treatability exemption found at 40 CFR $\$ 264.4(e)$ and $(f)$ as modified by 59 FR 8362 . Treatment technologies routinely evaluated by ARS include soil washing, mercury treatment and reclamation, resource recovery, wastewater treatment, and immobilization. ARS has the necessary resources and is engaged in developing new treatment methods for LLMW, such as rare earths and heavy metal recovery and recycling, soil washing, extraction and purification, and chemical fixation.

Afftrex, Ltd.: Afftrex is willing to conduct bench or pilot scale treatability studies on LLMW and is interested in developing new methods for treating LLRW and/or LLMW. Afftrex has performed some test applications for DOE facilities on the solidification of radioactively contaminated oily waste. The company would like to utilize its new Blackfoot, ID facility for LLRW and LLMW treatability studies.

ALARON Corporation: ALARON currently operates an NRC-licensed facility located in Wampum, Pennsylvania. ALARON is not currently permitted by the EPA and has no plans to apply for an EPA permit within the next five years. ALARON is not currently capable of performing treatability studies for LLMW. However, ALARON is interested in obtaining more specific information concerning the development of new treatment methods for LLMW. ALARON indicated that they do have laboratory and application test facilities that could be modified to conduct treatability studies. 
Allied Technology Group, Inc. (ATG): ATG operates facilities in California under a California radioactive materials license. Currently, ATG does not operate facilities permitted by the EPA. ATG literature indicates that they may be expanding their services in the future to include hazardous waste. Currently, ATG does not have the capability to conduct LLMW. treatability studies.

American Ecology Corporation: AEC currently operates under a radioactive materials license issued by the State of Tennessee. American Ecology has a RCRA permit to treat benchscale quantities of LLMW via thermal treatment. AEC can perform thermal treatment under a treatability exemption or research and development permit. The treatability exemption is promulgated at 40 CFR 264.4(e) and (f) (see 59 FR 8362 for final rule). AEC has the necessary resources and is interested in developing new treatment methods for LLMW using thermal treatment and decontamination methods.

Babcock and Wilcox Nuclear Environmental Services, Inc. (B\&W): B\&W capabilities and facilities are currently reserved solely for the support of waste management needs of The Babcock and Wilcox Company's Naval Nuclear Fuel Division. B\&W maintains a fully equipped research and development center at its Lynchburg Technology Center in Lynchburg, Virginia. B\&W has high-limit, source, by-product, and special nuclear material licenses allowing it to receive and possess virtually any LLMW sample for study.

COGNIS, Inc. (a division of the Henkel Corporation): COGNIS is Henkel's research arm in metal separation technology, based in California, whose primary interests are metals removal and recovery, removal of organic and mineral acids, resource management, wastewater treatment, mine detoxification, and analytical services. It has developed the only transportable soil treatment plant for heavy metals in the country which has been treating $100 \%$ of the excavated soil, returning the soil on-site, and recycling the recovered metals. COGNIS has been successful in employing its soil washing/soil leaching technology to treat the soil at the Twin Cities Army Ammunition Plant in New Brighton, MN for eight heavy metals. The company is licensed by the state of California to "receive, use, possess, transfer, or dispose of radioactive materials..."(License Number 4880-49). The license pertains to the use of very small quantities of specific nuclides used for labeling and as tracers in chemical and biological studies. COGNIS is interested in conducting studies and developing technologies for treating LLRW and LLMW.

Diversified Technologies: DT has applied for an NRC license to perform treatability studies and store and maintain equipment. They expect approval of the NRC license by May 1995. DT plans to operate fixed-base sites in Knoxville, Tennessee and near the Hanford site in Washington. They have the necessary facilities and resources and are interested in conducting treatability studies and developing new treatment methods for LLRW and LLMW. DT is currently pursuing thermosetting thermoplastic polymer solidification/stabilization for LLRW and LLMW and reverse osmosis for volume reduction of aqueous waste streams. It has already done development work for EG\&G Idaho, Inc. (now Lockheed Idaho Technologies Company) and the Naval Reactors Facility at INEL for limited applications. Currently DT's LLMW treatability studies are conducted at International Technology (IT) Corporation's facilities in Knoxville, Tennessee.

Duke Engineering and Services: Duke is only licensed/permitted to handle wastes generated at Duke Power company facilities. Duke operates under a radioactive materials license and a RCRA permit. However, the company can provide expertise concerning 
treatability studies of LMMW and is interested in conducting treatability studies for outside customers in the future.

Envirocare of Utah, Inc.: Envirocare owns and operates a treatment and disposal facility $120 \mathrm{~km}(75 \mathrm{mi})$ west of Salt Lake City, Utah. Envirocare operates under a radioactive materials license and a RCRA permit. Envirocare can currently accept LLRW and LLMW. Envirocare indicated that it is capable of conducting bench and pilot-scale treatability studies. Specific information was not provided.

Fluid Tech, Inc.: Fluid Tech operates a licensed laboratory that conducts treatability studies on the chemical stabilization of hazardous constituents of LLMW. Fluid Tech is actively involved in developing new and improved LLMW treatment methods and is interested in providing this service to the DOE.

Hazen Research, Inc.: Hazen operates its Golden, Colorado facility under a radioactive materials license issued by the State of Colorado. Hazen is also authorized by the Colorado Department of Health to conduct treatability studies on samples of waste that are listed and/or characteristic wastes at their site of generation. Hazen is a full-service research and development organization that can conduct bench and/or pilot-scale treatability studies on LLMW using physical, thermal, and chemical technologies. Hazen is interested in conducting LLMW treatability studies for the DOE.

IC Technologies (ICT): ICT currently does not have a radioactive materials license or a RCRA permit. ICT does conduct bench and pilot-scale treatability studies at its facility in Wheat Ridge, Colorado. Technologies that have been studied include polymer encapsulation, reactive metallurgy, cement solidification, solvent extraction, and radioactive material recycling. Specific mixed waste studies and on-site, full-scale demonstrations have been completed at the DOE Pantex facility utilizing specially formulated and applied polymers.

International Technology Corporation (IT): IT operates under a radioactive materials license issued by the State of Tennessee. IT conducts treatability studies in its Knoxville, Tennessee facility under the treatability exemption in the federal regulations that has been adopted by the Tennessee Department of Health and Environment. The treatability exemption is promulgated at 40 CFR 264.4(e) and (f) (see 59 FR 8362 for final rule). Testing on materials regulated under the Toxic Substances Control Act (TSCA) is covered by technology specific permits issued by Region N of the EPA or by EPA headquarters depending on the quantity of materials used for testing. IT currently operates under TSCA permits for the bench-scale testing of thermal technologies, stabilization, dechlorination, and other technologies. Treatability studies include but are not limited to the following technologies: stabilization, vitrification, thermal desorption, incineration, oxidation, wet oxidation, high pressure wet oxidation, soil washing, chemical extraction, absorption, and ion exchange. IT has the necessary resources for and is interested in developing new treatment methods for LLMW.

Nuclear Fuel Services, Inc.: NFS, located in Erwin, TN, and its subsidiary Advanced Recovery Systems (ARS) have the capability to conduct treatability studies to evaluate uranium recovery, establish sediment dewatering parameters, and develop treatment processes for RCRA components. The company maintains the onsite analytical capability to conduct laboratory and pilot scale studies of radioactive, hazardous, and mixed waste treatment processes. NFS has a permit for treatment of their own mercury contaminated 
mixed wastes and K-25 sludge. They have submitted a permit modification that will allow them to offer treatment of mixed wastes commercially.

Nuclear Metals, Inc.: NMI currently operates under a radioactive materials license and a RCRA permit at its facility in Barnwell, South Carolina. NMI routinely develops bench and pilot-scale processes for LLRW. NMI will offer treatability study services for LLMW. Once the study is complete and the preferred method chosen, it will pursue the method through bench and pilot-scale operations.

RUST Federal Services, Inc:: RUST currently operates under a radioactive materials license and a RCRA permit. RUST operates a $3,700 \mathrm{~m}^{2}\left(40,000 \mathrm{tt}^{2}\right)$ mixed waste technology demonstration and development facility, the Clemson Technical Center, in Anderson, South Carolina. RUST can perform bench and pilot-scale testing for numerous treatment technologies, including stabilization/solidification, vitrification, wet oxidation, thermal desorption, sludge drying, soil washing, thermal desorption, bioremediation, and dechlorination. RUST can also manage field demonstrations from the facility.

Scientific Ecology Group, Inc.: SEG currently operates under a radioactive materials license and an interim status RCRA permit. SEG expects to receive a RCRA Part B permit to treat, store, or dispose of LLMW in 1995. SEG has a permit to conduct bench and pilot-scale treatability studies on LLMW at its laboratories in Oak Ridge, Tennessee and Pittsburgh, Pennsylvania. Stabilization and vitrification testing have been successfully performed on a variety of LLMWs. SEG has the resources for and is interested in developing new treatment methods for LLMW.

\section{LLRW Decontamination and Recycling Services}

Advanced Recovery Systems, Inc.: ARS, a subsidiary of Nuclear Fuel Services, Inc., has completed several resource recovery projects in evaluations of wastes and has successfully demonstrated its expertise in the recovery of rare earth and precious metals. Project experience also includes recovery of tantalum, niobium, scandium, uranium, thorium, radium, lead, arsenic, zirconium, yttrium, mercury, and fluorine from a variety of waste forms. ARS has used its proprietary processes including DeCaF, DeHg, DeAct, DeCl, TherMag, and CrystX to decontaminate LLRW for metals reuse, recycling and/or free release.

Afftrex, Ltd.: Afftrex performs decontamination of LLRW metals service at several DOE sites. The primary decontamination techniques used are broadly classed as mechanical and chemical. Techniques include grinding, sanding, machining, chemical wiping, and strippable paints.

ALARON Corporation: The ALARON Northeast Regional Service Facility located in Wampum, Pennsylvania decontaminates LLRW metals by destructive and nondestructive techniques. These techniques were listed in the information provided by the company, but were not described. The techniques listed are chemical etching, multi-media abrasive blasting, needle scaling, grinding, and manual wipe-down. ALARON is also capable of using customer specified techniques for decontamination. Their on-site capacity is $2,300 \mathrm{~m}^{3}$ $\left(80,000 \mathrm{ft}^{3}\right)$, as stated in response to the questionnaire. The company's two NRC licenses, Nos 37-20826-01 and 37-20826-02, allow it to accept radionuclides with atomic numbers from 1 to 96 , depleted uranium, and source and special nuclear material. License No. 37-20826-01 
was to expire in 1990, but has been extended indefinitely. In the 1994 survey, it was stated that License No. 37-20826-02 expired September 30, 1994, but was expected to be extended.

Allied Technology Group, Inc.: ATG's decontamination facility located in Richland, Washington uses techniques such as grit blasting, plasma arc, mechanical descaling, electropolishing, freon cleaning, and high-pressure water blasting. ATG also operates facilities in California under a California radioactive materials license. Currently, ATG does not operate facilities permitted by the EPA. ATG literature indicates that they may be expanding their services in the future to include hazardous waste. ATG provides services to decontaminate filters, machinery, equipment, and other contaminated items. ATG provides these services on site and at client facilities using mobile decontamination units.

American Ecology Corporation (AEC): AEC can decontaminate metals that are surface-contaminated. AEC is licensed by the State of Tennessee to decontaminate radioactive materials and to unconditionally release those materials determined to have been decontaminated below stated license limits. AEC is licensed to process up to $28,000 \mathrm{~m}^{3}$ $\left(1.0 E+06 \mathrm{ft}^{3}\right)$ of waste annually. The recycle center's license (No. R-01037-J95) expires October 31,1995 . The license allows the facility to accept waste containing mixed activation and mixed fission products with atomic numbers from 3 to 83 , source material such as natural or depleted uranium, small quantities of special nuclear material and transuranics, and sealed sources. The recycle center has processed a total of $85,000 \mathrm{~m}^{3}\left(3.0 \mathrm{E}+06 \mathrm{ft}^{3}\right)$ of metallic materials, approximately 80 percent of which have either been sold as scrap on the metals market or returned to productive use. The processes employed by AEC for decontaminating metals were listed, but were not described. The methods listed are abrasive decontamination, chemical decontamination, electrochemical decontamination, and shear stress cleaning.

Babcock and Wilcox Nuclear Environmental Services, Inc.: B\&W capabilities and facilities are currently reserved solely for the support of waste management needs of The Babcock and Wilcox Company's Naval Nuclear Fuel Division. B\&W maintains a fully equipped research and development center at its Lynchburg Technology Center in Lynchburg, Virginia. B\&W has high-limit, source, by-product, and special nuclear material licenses and performs decontamination and recycling operations for LLRW.

Bartlett Nuclear, Inc.: Bartlett has developed a cleaning agent called BY^PAS Decontamination Chemical, which is approved for use at many reactor facilities. Bartlett's Sonatol Process uses an inert organic solvent and a carefully designed surfactant in an ultrasonic bath to remove loose and tightly adhered radioactive particles from surfaces. The Sonatol process also includes real time monitoring of the decontamination activity to optimize the process time for each batch of contaminated objects.

British Nuclear Fuels Limited, Inc.: BNFL has a patented process for soil treatment called CACITOX originally developed for nuclear fuel reprocessing. BNFL is extending the patent to treat soil contaminated with heavy metals and transuranic elements. CACITOX is a leaching process that uses a reagent to dissolve particulates and adsorb contaminants from the soil while leaving the basic matrix intact. BNFL plans to build a transportable plant that uses this process in the near future. Also, BNFL and Raytheon Engineers and Constructors have formed a team which has an interest in providing turnkey radioactive mixed waste treatment services for the INEL. 
Diversified Scientific Services, Inc.: Although DSSI claimed expertise in this field in both the 1994 and 1995 surveys, no information on their capabilities was provided.

Interstate Nuclear Services Corporation (INS): INS provides on-site mobile metal decontamination units which employ state-of-the art cleaning methods for metals recovery and waste reduction.

Non-Destructive Cleaning, Inc. (NDC): NDC supplies nondestructive cleaning systems and predesigned facilities. The systems and facilities that are sold are somewhat unique in that they use $\mathrm{CO}_{2}$ to clean contaminated material, leaving behind no secondary contamination such as contaminated water. NDC's decontamination facilities are all mobile units; the company does not supply any other decontamination services.

Nuclear Fuel Services, Inc.: Although NFS claimed expertise in this field in their response to this survey, no specific information was provided concerning the company's capabilities.

Nuclear Metals, Inc. (NMI): NMI currently operates under a radioactive materials license and a RCRA permit. NMI plans to obtain a RCRA permit for their Depleted Uranium Recycle Facility located in Barnwell, South Carolina. NMI has developed the "Denver process" to extract uranium, lead, and other metals from LLRW sludge and soils. This process involves a washing/leaching step that solutionizes the radioactive constituents so they can be separated for possible recycling. The metals as precipitates or leachate residues are generally recovered free of radioactive contamination. The recovered nonradioactive metals can then be reintroduced into an unrestricted end use because the radioactive component of the waste stream has been removed. The company has demonstrated this technology with a pilot plant designed to handle $2,700 \mathrm{~kg} /$ day $(6,000 \mathrm{lb} /$ day). NMl reports that a full-scale plant could be on line in 9 to 15 months if needed. NMI has also developed the Hydromet process to process uranium and uranium alloy scrap; such as machine turnings, grinding swarf and foundry scrap; into high-quality metal. The Hydromet process allows alloying elements such as titanium, molybdenum, and niobium to be fully recovered. In addition, NMI uses a high-pressure water jet technique and other abrasive methods to decontaminate equipment and facilities.

RUST Federal Services, Inc.: RUST currently operates under a radioactive materials license and a RCRA permit. RUST decontaminates LLRW metal-contaminated soil for reuse or recycling using acid extraction and selective dissolution methodologies. Decontamination operations are conducted at RUST's facility in Anderson, South Carolina. Capacity is determined by the radionuclide limits in RUST's NRC license. RUST has extensive capabilities to develop treatment and decontamination methods. For metals decontamination, RUST specifies acid extraction and selective dissolution as examples of methods it employs. RUST has also provided a pilot-plant demonstration to extract radionuclides and metals from INEL soils and sludges. RUST expressed a willingness to provide treatment and decontamination systems and services when DOE defines a need for its services.

Scientific Ecology Group, Inc.: SEG currently operates under a radioactive materials license and an interim status RCRA permit. SEG expects to receive a RCRA Part B permit to treat, store, or dispose of LLMW in 1995. SEG decontaminates and recycles LLRW metals. SEG states that is has the largest, most technologically advanced metal decontamination facility with the only dedicated foundry for radioactive metals in the United States. Most 
metals are decontaminated via high-pressure water, steel shot, or glass bead blasting. Metals, including steel, stainless steel, copper, brass, and lead, are routinely released by SEG. SEG also melts LLRW metal into blocks used for shielding at DOE facilities. Stainless steel, carbon steel, and aluminum are commonly processed in this fashion. In 1994 SEG processed and released over $280,000 \mathrm{~kg}(627,000 \mathrm{lb})$ of contaminated metals for unrestricted use.

For metals that cannot be decontaminated by surface decontamination techniques, SEG operates a furnace that has a capacity to melt approximately $12 \mathrm{E}+06 \mathrm{~kg}$ per year $(13,000$ tons per year). The molten metal is then molded into customized shielded waste containers or shielding blocks for reuse. SEG accepts a large number of radionuclides, including mixed fission products and transuranic waste contaminated to levels below $10 \mathrm{nCi} / \mathrm{g}$. The total limit for radionuclides is $800 \mathrm{Ci}$ with additional limitations of $700 \mathrm{~g}$ for ${ }^{235} \mathrm{U}, 400 \mathrm{~g}$ for ${ }^{238} \mathrm{U}$, and $400 \mathrm{~g}$ for all plutonium. All Oak Ridge area facilities operated by SEG hold current licenses from the State of Tennessee.

U.S. Ecology: U.S. Ecology currently operates under a radioactive materials license issued by the State of California. In the 1994 survey, it was stated that U.S. Ecology expected to obtain a radioactive materials license from the State of Nebraska in 1995. No further information was supplied in response to the 1995 request. The company currently does not have a RCRA permit, but is planning to apply for a RCRA permit for thermal treatment of LLMW. U.S. Ecology decontaminates LLRW for metals reuse, recycling, and/or free release, but only for institutional clients, hospitals, and universities.

\section{Storage and Disposal of LLMW}

Envirocare of Utah, Inc: Envirocare owns and operates a treatment and disposal facility $120 \mathrm{~km}$ (75 miles) west of Salt Lake City, Utah. Envirocare can currently accept LLRW and LLMW for disposal. Envirocare operates under a radioactive materials license and a RCRA permit. Its radioactive materials license has recently been amended to allow the acceptance of 63 isotopes. The concentration limits are low and specific to each isotope. Acceptable hazardous wastes include characteristic waste codes D001 through D043, listed wastes F001 through F012, F019, F024, F028, F039, K011, K013, K050, K051, K052, K061, K069, and several P-listed and U-listed wastes.

Nuclear Fuel Services, Inc.: Although NFS claimed to have the capacity to store and treat LLMW, no specific details were provided in the company's response to this survey.

Nuclear Metals, Inc.: NMI currently operates under a radioactive materials license and a RCRA permit. NMI currently has an annual LLMW storage capacity of $2.8 \mathrm{~m}^{3} / \mathrm{yr}\left(100 \mathrm{ft}^{3} / \mathrm{yr}\right)$ and an annual LLMW disposal capacity of $2.8 \mathrm{~m}^{3} / \mathrm{yr}\left(100 \mathrm{ft}^{3} / \mathrm{yr}\right)$ at its plant in Barnwell, South Carolina. NMI is not licensed currently to store commercial quantities of LLMW. 


\section{Laundering of Radioactively-Contaminated Laundry and/or Respirators}

Afftrex, Ltd.: Afftrex owns and operates a NRC-licensed facility in Clairton, PA which is capable of laundering contaminated protective clothing and other items, including respirators, contaminated with radioactivity and/or asbestos.

Bartlett Nuclear, Inc:: Bartlett manufactures a Mobile Respirator Decontamination system which includes a complete wash line with deep sink, washer, HEPA vacuum, drying oven, and survey area; complete water reprocessing system with a 5 micron particulate filter, activated charcoal, and mixed bed resin system, and a 48 foot trailer with air conditioning, nuclear grade HEPA system, and HALON 1301 fire suppression system. The system provides automated controls for water temperature, water quality, drying cabinet temperature, water level, and flow rate.

Eastern Technologies, Inc. (ETI): ETI presently operates a laundering facility for radioactively-contaminated clothing and respirators in Ashford, Alabama. Currently, this facility is operating at one-fourth of its maximum capacity of 43,092 pounds per day. The facility operates under a state radioactive materials license (Number: Alabama 947). An aqueous-borne ozone cleaning system is used for cleaning of protective clothing, modesty garments and other launderable items (i.e., bath towels, mop heads, decon towels, etc.). ETI maintains separate equipment to process contaminated and non-contaminated items, to ensure that cross contamination does not occur.

In addition to the fixed-base Alabama facility, ETI provides mobile on-site water wash services. The mobile facility also utilizes the aqueous-borne ozone cleaning system. Two sizes of mobile units are available, rated at 1,400 and 2,400 sets per twenty-four hours. Services available with the mobile units include water wash processing of protective clothing, monitoring of processed clothing, repair of protective clothing, and cleaning and drying of respirators and related equipment (approximately 400 units per twenty-four hours). The mobile water wash laundry systems are designed to operate in two modes (i.e., full recycle or partial recycle) depending on discharging requirements. ETI's mobile system is comprised of three trailers ( 1 at $8^{\prime}$ by $45^{\prime}$ and 2 at $8^{\prime}$ by $53^{\prime}$ ).

All laundry is monitored by an Automated Radioactive Laundry Monitor (ARLM). The monitor utilizes upper and lower overlapping high efficiency (<7000 dpm for most isotopes) gas flow proportional detectors to survey protective clothing items on all sides simultaneously. Alarm set points utilized on the ARLM can be customer specified.

Interstate Nuclear Services Corporation (INS): INS has been a supplier of radiological laundry and protective clothing programs for 38 years. INS presently operates 14 different laundering facilities in support of the commercial nuclear industry, Naval shipyards, DOE, and private industry. The typical wash capacity at INS facilities is approximately 2,000 pounds per hour. The Hanford facility is the largest INS facility, cleaning up to 3,500 pounds per hour. The Hanford facility in Richland Washington operates under a state radioactive materials license (Number WN-10414-1). All INS facilities provide protective wear decontamination, respirator decontamination and recertification, and tool and metal decontamination. Five models of laundry monitors are used at INS facilities. Each one has been designed for a specific application (low-level contamination monitoring, alpha monitoring, large area monitoring, hot particle monitoring, etc.). INS also provides on-site mobile water wash units 
capable of processing $\mathbf{3 5 0}$ pounds per hour; respirator cleaning, inspection and recertification; and respirator filter cartridge testing and recertification. All respirator work is performed in compliance with NUREG 0041. Protective clothing and equipment sales and leasing is also available through INS.

Nuclear Fuel Services, Inc. (NFS): In their response to this survey, NFS claimed to have the resources to provide this service. However, they did not provide any specific information on their capabilities in this area.

Octagon/Power Systems Energy Services, Inc. (PSES|): PSESI has developed a complete mobile wet laundry system. The system can be assembled at any location on a temporary or permanent foundation. The system occupies an area of approximately 30 feet by 48 feet and includes facilities for washing, drying, folding, and repair of protective clothing as well as respirator servicing. The facility provides HEPA filtration and water treatment for all process effluents. An optional shipping and receiving shelter can be added to the system to provide a fully covered laundry facility. 


\section{CONCLUSION}

The results of this survey indicated that 24 companies can provide some beneficial radioactive and mixed waste services for the seven waste categories. Five companies who were identified in the 1994 survey did not respond to this survey and one company, Applied Radiological Control, Inc., asked to be removed from the report. The five companies that did not respond include ALARON Corporation, Allied Technology Group, Inc., $\pi$ Corp., NonDestructive Cleaning, Inc., and U.S. Ecology. Information on these companies from the 1994 report was included in this report unchanged.

\section{REFERENCES}

40 CFR \$264.4, July 1, 1991, "Exclusions," Code of Federal Regulations, Washington, D.C., Office of the National Archives and Records Administration.

59 FR 8362, 1994, "Hazardous Waste Management System: Identification and Listing of Hazardous Waste Treatability Studies Sample Exclusion," Federal Register 59 (February 18): pp. 8362-8366.

American Nuclear Society, 1993, Nuclear News: Buyers Guide for 1993, Vol. 36/No. 4, pp. 261 $-267$.

American Nuclear Society, 1992, World Directory of Radwaste Managers, 1st. Edition, pp. 173191.

Garrison, T. W. and J. D. Mousseau, to K. E. Kooda, 1993, Private Sector Participation Initiative (PSPI) Private Sector Status Report, April.

NUREG/CR-5938, 1992, National Profile on Commercially Generated Low-Level Radioactive Mixed Waste, U. S. Nuclear Regulatory Commission, December.

Piper, R. B. and J. D. Mousseau, to R. R. Piscitella, 1993, Private Sector Participation Initiative (PSPI) Letter Report for Private Sector Treatment of Idaho National Engineering Laboratory Flammable Low-level Mixed Waste, September.

Smith, Miles, et. al., Review of Private Sector Treatment, Storage, and Disposal Capacity for Radioactive Waste, Lockheed Idaho Technologies Company, INEL Report No. INEL-95/0020, January 1995.

Taylor, D. D., Private Sector Initiative Vendor Forum (1994), Lockheed Idaho Technologies Company, INEL Report No. INEL-94/002, October 1994. 


\section{APPENDIX A}

Vendor Contact Telefax Form

A-1 
Date: April 19, 1995 Pages to Follow: $0 \quad$ From: Shaun L. Gibson Project \#: 5033.03.0001

To: Name and Address of Vendor / Attn: Name of Contact

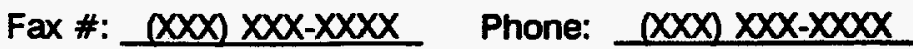

Please take a moment to complete the following checklist. The information you provide will be included in a resource report to be provided to the Idaho National Engineering Laboratory. This report is also circulated throughout the DOE complex to identify potential vendors for low-level radioactive and mixed waste support. Please direct any questions and telefax the completed checklist to the person identified above. In addition, please send two copies of your company's most current brochure, statement of qualifications, or other information on the type of services you provide.

Place a check to Identify services your company can provide:

Laundering of radioactively-contaminated laundry and/or respirators

Low-Level Radioactive Waste Storage

Low-Level Radioactive Waste Volume Reduction

Decontamination of Low Level Radioactive Waste Metals

Low-Level Radioactive Waste Decontamination/Recycling

Low-Level Mixed Waste Storage

Low-Level Mixed Waste Treatability Studies

Low-Level Mixed Waste Treatment

Low-Level Mixed Waste Treatment (Alpha-contaminated $\leq 100$ nanocuries per gram)

Low-level Mixed Waste Disposal

Identify the licenses and permits applicable to your facllity:

(Circle the activity addressed by the license)

Laundering / Treatment / Storage / Disposal of Low-Level Radioactive Waste:

NRC License \#:

Authorized State License \#:

Expiration Date:

Expiration Date:

(Circle the activity addressed by the license/permit)

Laundering / Treatment/ Storage / Disposal of Low-Level

Mixed Waste:

NRC License \#:

EPA Permit \#:

Authorized State License/Permit \#:

Expiration Date:

Expiration Date:

Expiration Date:

Is your company currently applying or planning to apply for a license or permit to treat, store, or dispose of LLRW or LLMW? If so please specify: 


\section{APPENDIX B}

Vendor Contact Follow-Up Form

B-1 
BENCHMARK

ENVIRONMENTAL CORPORATION
4501 Indian School Road NE, Suite 105

Albuquerque, New Mexico 87110

(505) 262-2694 Fax (505) 262-2698

Date: April 19, 1995 Pages to Follow: $0 \quad$ From: Shaun L Gibson Project \#: 5033.03 .0001

To: Name of Contact Vendor Name

Vendor Address

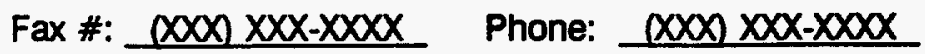

Please take a moment to review the following narrative. It has been compiled from the information you have provided. If you have any other information or can revise the narrative to make it more accurate please provide comment by telefax. Remember this is an independent report so the narrative must be neutral and not include verbiage that implies a solicitation. Please direct any questions to the person identified above.

Place a check to Identify services your company can provide:

$\underline{X}$ Laundering of radioactively-contaminated laundry and/or respirators

Low-Level Radioactive Waste Storage

Low-Level Radioactive Waste Volume Reduction

Decontamination of Low Level Radioactive Waste Metals

Low-Level Radioactive Waste Decontamination/Recycling

Low-Level Mixed Waste Storage

Low-Level Mixed Waste Treatability Studies

Low-Level Mixed Waste Treatment

Low-Level Mixed Waste Treatment (Alpha-contaminated $\leq 100$ nanocuries per gram)

Low-Level Mixed Waste Disposal

\section{Current narrative:}

Name of Vendor

Narrative for Vendor

Notes to Vendor 


\section{APPENDIX C}

Vendor Profiles

C-1 


\begin{tabular}{|c|c|c|}
\hline $\begin{array}{l}\text { nep. } \\
\text { Phone: } \\
\text { FAX: }\end{array}$ & $\begin{array}{l}\text { Schutt, Paul } \\
(404) 4476956 \\
(404) \times 6628415\end{array}$ & $\begin{array}{l}3945 \text { Holcomb Bridgerd. } \\
\text { Suite } 202 \\
\text { Atlanta, GA } 30092\end{array}$ \\
\hline
\end{tabular}

\section{Services Provided:}

X Low-Level Radioactive Waste Volume Reduction

$X \quad$ Low-Level Mixed Waste Treatment

$X \quad$ Low-Level Alpha-Contaminated Mixed Waste

$X \quad$ Low-Level Mixed Waste Treatability Studies

$X \quad$ Low-Level Radioactive Waste Decontamination/Recycling

Low-Level Mixed Waste Storage and Disposal

Laundering of Radioactively-Contaminated Laundry and/or Respirators

\section{Overview:}

Advanced Recovery Systems, Inc. (ARS), formerly Ekotek and a subsidiary of Nuclear Fuel Services Technologies, Inc., has resources and staff to perform treatability studies, bench and pilot-scale studies, design of systems, and on-site support for $L R W$ and LUMW activities. ARS has a patented process to treat a variety of hazardous and mixed wastes, as shown below. ARS has a radioactive material license issued by the State of Tennessee.

$\begin{array}{lll}\text { - } & \text { DeCaF } & \text { Recovery of fluorine and metal from radioactive wastes } \\ \text { - } & \text { DeHg } & \text { Mercury treatment process } \\ \text { DeAct } & \text { Soil washing to extract actinide contamination } \\ \text { DeCl } & \text { Recovery of rare earths and scandium from process residues } \\ \text { - TherMag } & \text { Recovery of fluorine, magnesium, and uranium from refractive waste }\end{array}$

\section{Current Capabilities:}

ARS maintains a treatability laboratory in Enwin, TN and can conduct hazardous and mixed waste treatability studies to develop process flow diagrams and mass and energy balances. Pilot-scale studies can be conducted to test extraction process effectiveness and full-scale plants can be designed based on the derived data from pilot studies. ARS provides consulting services in recovery evaluation of radionuclides, precious metals, and rare earth metals from a variety of waste forms.

\section{Future Capabilities:}

ARS continues to develop and apply their current technologies while evaluating and developing complementary technologies for growth within the federal and commercial marketplace.

Permits and LIcenses:

- Tennessee Radioactive Materials License No. R-86008-D97, expires April, 301997

- NRC mobile Radioactive Materials License No. 41-25193-01, expires April 30, 1997

- Under treatability exemption, can accept $1,000 \mathrm{~kg}(2,200 \mathrm{lb})$ of mixed/hazardous waste for treatability studies 
AFFTREX, LTD.

\begin{tabular}{|c|c|c|}
\hline Plep: & $\begin{array}{l}\text { Buton, Douglas } \\
(208), 7857470 \\
(208) 7856308\end{array}$ & $\begin{array}{l}395 \text { West Highway } 39 \\
\text { Blackfoot, lD } 83221\end{array}$ \\
\hline
\end{tabular}

Services Provlded:

X Low-Level Radioactive Waste Volume Reduction

Low-Level Mixed Waste Treatment

Low-Level Alpha-Contaminated Mixed Waste

$X \quad$ Low-Level Mixed Waste Treatability Studies

$X \quad$ Low-Level Radioactive Waste Decontamination/Recycling

Low-Level Mixed Waste Storage and Disposal

$X \quad$ Laundering of Radioactively-Contaminated Laundry and/or Respirators

\section{Overview:}

Since 1981 Afftrex has been providing scientific, engineering, and technical radioactive decontamination, decommissioning and environmental mixed waste services to clients such as the Bettis Atomic Power Laboratory (BAPL), West Mifflin, Pa., Martin Marietta K-25 Gaseous Diffusion Plant, Oak Ridge, TN.,Naval Reactors Facility (NRF) at the idaho National Engineering Laboratory (INEL), Idaho Falls, ID, Knolls Atomic Power Laboratory (KAPL), Schenectady, NY, Los Alamos National Laboratory (LANL), Los Alamos, NM, and Sandia National Laboratories (SNL), Albuquerque, NM, and the Uranium Mill Tailings Remedial Action (UMTRA) Program at Canonsburg, PA. Afftrex is experienced in the design, construction, testing, and use of radiological containments to control contamination spread.

\section{Current Capabilities:}

Volume Reduction: Afftrex provides volume reduction treatment service for LLRW at several DOE facilities including NRF at INEL, Bettis Atomic Power Laboratory, and Oak Ridge National Laboratories.

LRW Decontamination/Recycling: Afftrex performs this service at the DOE facilities listed above. Aftrex offers decontamination services for projects ranging from localized "hot spots" to an entire site.

Treatability Studies: Afftrex is willing to conduct bench or pilot scale treatability studies of LLMW. The company is knowledgeable of analytical requirements and is familiar with testing procedures. Afftrex has the facilities and resources and is interested in developing new treatment methods for LLRW and LLMW at its Clairton, PA facility and at the new Blackfoot, ID facility. Afftrex is interested in establishing a fixed base for R\&D processes or commercial activities at its Blackfoot, ID facility.

Laundry Services: The company owns and operates a NRC-licensed laundry facility which is capable of laundering protective clothing and other items contaminated with radioactivity and/or asbestos. 


\section{Future Capabllities:}

Afftrex has applied for an NRC Broad Scope Type A License to use by-product material at its Blackfoot, ID facility. Other radiological activities may be added to the above license by addendum or addition as the need arises. Afftrex is interested in establishing a fixed-base operation at its new Blackfoot, ID facility to perform such activities as treatment/segregation of lead blankets, treatment of radioactive NAK, and super compacting, segregation, sizing, and decontamination of URW. Also, Afftrex has proposed that its Blackfoot facility be used to conduct pilot tests of SAIC's plasma arc fumace radioactive material treatment concept.

\section{Permits and Licenses:}

Afftrex is licensed by the NRC for the laundering of radioactively contaminated clothing and respirators at its Clairton, PA nuclear laundry facility. License Number 37-28329-01.

Afftrex is licensed by the Allegheny County Health Department for the removal and disposal of radioactively contaminated asbestos containing materials in Allegheny County, Pennsylvania. License Number ACAL-93-8047. 


\begin{tabular}{|c|c|c|}
\hline $\begin{array}{l}\text { Rep: } \\
\text { Phone? } \\
\text { EAx: }\end{array}$ & $\begin{array}{l}\text { Taylor, James } \\
(803) 791 \text {. } 9900 \\
(803) 791-991 \text {. }\end{array}$ & $\begin{array}{l}\text { Park Place, Suite } 500 \\
440 \text { Knox Abbol Brive } \\
\text { Casey, SC } 29033\end{array}$ \\
\hline
\end{tabular}

\section{Services Provided:}

$X \quad$ Low-Level Radioactive Waste Volume Reduction Low-Level Mixed Waste Treatment Low-Level Alpha-Contaminated Mixed Waste

X Low-Level Mixed Waste Treatability Studies

$X \quad$ Low-Level Radioactive Waste Decontamination/Recycling Low-Level Mixed Waste Storage and Disposal Laundering of Radioactively-Contaminated Laundry and/or Respirators

\section{Overview:}

ALARON Corporation's Nuclear Utility Services Division (NUSD) provides radioactive waste management, spent fuel pool management, spent fuel pool decontamination and decommissioning, tank desludging, and decontamination and decommissioning of areas and facilities. NUSD provides irradiated hardware consolidation for packaging, disposal, or storage.

\section{Current Capabilities:}

NUSD segments and dense packages metals and compacts/supercompacts dry active waste. NUSD decontaminates metal using destructive and nondestructive chemical cleaning, abrasive blasting, and low and high-pressure wash methods. NUSD can decontaminate $\angle M W$, but it is limited to certain characteristic wastes in small quantities only.

\section{Future Capabilities:}

NUSD is interested in using its laboratory and application test facilities to develop new treatment methods for LLRW/LLMW.

\section{Permits and Licenses:}

- NRC License No. 37-20826-01, for possession, storage, maintenance, repair, and decontamination of contaminated equipment and for possession, storage, and use as calibration and check sources

- NRC License No. 37-20826-02, for receipt, possession, storage, and repackaging dry lowspecific activity (LSA) waste materials as defined in 49 CFR Part 173.403(n) 


\begin{tabular}{|c|c|c|}
\hline Pepl: & $\begin{array}{l}\text { Wison, Michael l } \\
(510) \text {. } 4903008) \text {. } 6513731\end{array}$ & $\begin{array}{l}47375 \text { Fremont Blvd } \\
\text { Fremont, CA } 94538 \text {. }\end{array}$ \\
\hline
\end{tabular}

\section{Services Provided:}

X Low-Level Radioactive Waste Volume Reduction Low-Level Mixed Waste Treatment Low-Level Alpha-Contaminated Mixed Waste

$X \quad$ Low-Level Mixed Waste Treatability Studies

$X \quad$ Low-Level Radioactive Waste Decontamination/Recycling Low-Level Mixed Waste Storage and Disposal Laundering of Radioactively-Contaminated Laundry and/or Respirators

\section{Overview:}

Allied Technology Group, Inc. (ATG) and subsidiary Allied Ecology Services, Inc. provide decontamination, volume reduction, waste minimization, and packaging services. ATG has permits or licenses in the States of California, Washington, and Nevada. ATG operates a licensed volume reduction and supercompaction facility in Richland, Washington.

\section{Current Capabilities:}

ATG has the resources to provide decontamination and decommissioning, volume reduction, supercompaction, site remediation, packaging, and container fabrication services. Decontamination techniques include grit blasting, plasma arc, mechanical descaling, electropolishing, Freon cleaning, and high pressure water blasting. ATG provides both on-site and mobile decontamination unit services.

\section{Future Capabilities:}

ATG is planning to expand their services to include chemical hazardous waste. ATG requests that customers contact them for planned or implemented service expansions.

\section{Permits and Licenses:}

- California Radioactive Materials License No. 2873-60, expires May 1997

- U.S. Environmental Protection Agency Transporters No. CAD-98-248-2317

- California Hazardous Waste Haulers Permit No. 1410

- Washington State Site Use Permit No. 2242

- Nevada State Site Use Permit No. Q-453 


\section{AMERICAN ECOLOGY CORPORATION}

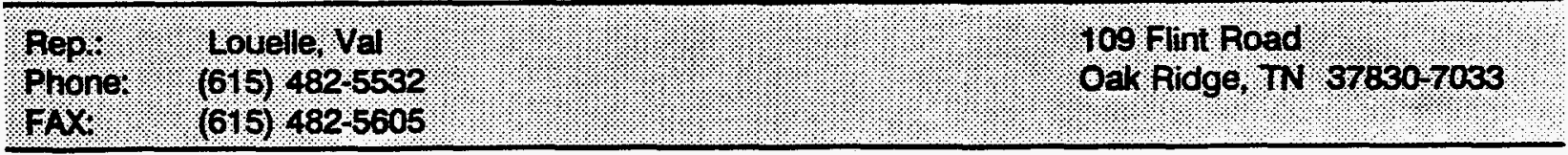

\section{Services Provided:}

X Low-Level Radioactive Waste Volume Reduction

$X \quad$ Low-Level Mixed Waste Treatment

Low-Level Alpha-Contaminated Mixed Waste

X Low-Level Mixed Waste Treatability Studies

$X$ Low-Level Radioactive Waste Decontamination/Recycling

Low-Level Mixed Waste Storage and Disposal

Laundering of Radioactively-Contaminated Laundry and/or Respirators

\section{Overview:}

The American Ecology Recycle Center, operated by American Ecology Environmental Company, a wholly owned subsidiary of American Ecology Corporation (AEC), is licensed by the State of Tennessee to sort and process radioactive materials for reuse or disposal. AEC surveys and unconditionally releases materials proven to be below stated limits of release or prepares them for disposal by burial.

\section{Current Capabilities:}

AEC sorts radioactive materials into material types to enhance nuclear decontamination and recycling processes. AEC uses abrasive, chemical, electrochemical, and shear stress cleaning decontamination processes to decontaminate radioactively contaminated materials for recycling. Volume reduction is accomplished through compaction and super compaction methods. Survey for release is used to determine those decontaminated materials that are below stated limits and can be recycled for reuse and those that must be processed and packaged for burial. AEC is capable of conducting bench-scale or pilot-scale treatability studies under treatability exemptions or specific R\&D permits.

\section{Future Capabilities:}

AEC is interested in developing new decontamination and thermal treatment methods.

\section{Permits and Licenses:}

- Radioactive Material License No. R-01037-J95 issued by the Tennessee Department of Health and Environment, Division of Radiological Health, expires October 31, 1995

- Hazardous constituents/EPA Waste Codes accepted: NA 
- Radionuclides accepted and associated license limits: (See below)

\begin{tabular}{|c|c|c|}
\hline $\begin{array}{l}\text { Radioactive Material (Element } \\
\text { and Mass Number) }\end{array}$ & Chemical and/or Physical Form & $\begin{array}{l}\text { Maximum Radioactivity and/or } \\
\text { Quantity of Material Which } \\
\text { Licensee May Possess at Any } \\
\text { One Time }\end{array}$ \\
\hline $\begin{array}{l}\text { A. Mixed activation and fission } \\
\text { products with atomic numbers } \\
3-83 \text { inclusive, (excluding C- } \\
\text { 14). }\end{array}$ & $\begin{array}{l}\text { A. Any form as suitable for } \\
\text { transport under U.S. DOT } \\
\text { Regulations. }\end{array}$ & A. 100 Curies \\
\hline $\begin{array}{l}\text { B. Source Material, (natural or } \\
\text { depleted uranium, or thorium) }\end{array}$ & B. Same as A & B. 10 Curies \\
\hline C. Uranium-233 & C. Same as A & C. 200 grams \\
\hline D. Uranium-235 & D. Same as A & D. 350 grams \\
\hline E. Plutonium & E. Same as A & E. 200 grams \\
\hline $\begin{array}{l}\text { F. Am-241, Am-242, Cm-242, } \\
\text { Cm-243, Cm-244, Np-237, and } \\
\text { Fm-257 }\end{array}$ & F. Same As A & F. 1 Curie \\
\hline $\begin{array}{l}\text { G. Radioactive materials with } \\
\text { atomic numbers } 82 \text { through } 91 \\
\text { inclusive, (excluding source } \\
\text { material) }\end{array}$ & G. Same as $\mathrm{A}$ & G. 10 Curies \\
\hline H. Hydrogen-3 & H. Same as A & $\begin{array}{l}\text { H. } 150 \text { Curies until November } \\
30,1992 \text { then } 100 \text { Curies } \\
\text { thereafter. }\end{array}$ \\
\hline I. Carbon-14 & I. Same as A & I. 50 Curies \\
\hline $\begin{array}{l}\text { J. Calibration and } \\
\text { Standardization Sources listed } \\
\text { in these sealed sources and } \\
\text { devices catalog and } \\
\text { distributed under a specific } \\
\text { license issued by the U.S. } \\
\text { NRC, the Department, or } \\
\text { another Agreement State. }\end{array}$ & J. Sealed Source & $\begin{array}{l}\text { J. No single source to exceed } \\
1 \text { millicurie }\end{array}$ \\
\hline K. Cesium-137 & $\begin{array}{l}\text { K. Sealed Source (Various } \\
\text { Types - See License for } \\
\text { details)) }\end{array}$ & $\begin{array}{l}K \text { One (1) source not to } \\
\text { exceed } 1.2 \text { curies. }\end{array}$ \\
\hline
\end{tabular}

Authorized State License/Permit \#R-01037-J95, expiration date October 31, 1995 
BABCOCK AND WILCOX NUCLEAR ENVIRONMENTAL SERVICES, INC.

\begin{tabular}{|c|c|c|}
\hline $\begin{array}{l}\text { Rep: } \\
\text { Phone: }\end{array}$ & 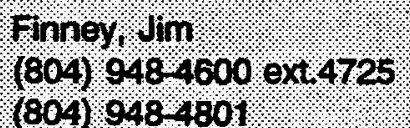 & 220 Langhome noad \\
\hline
\end{tabular}

\section{Services Provided:}

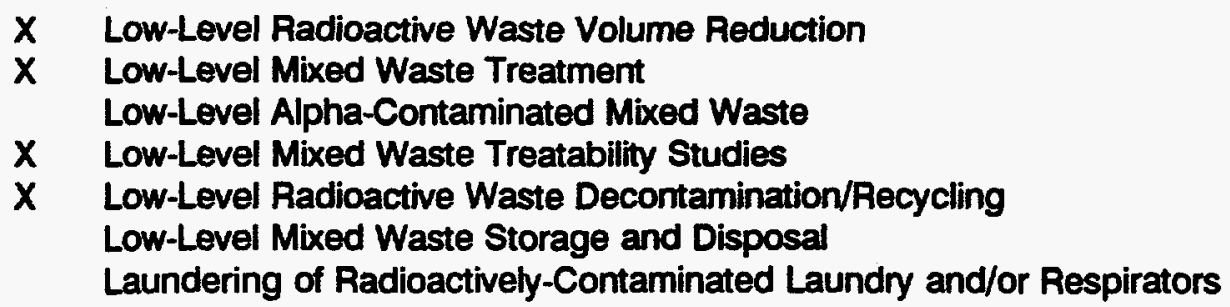

\section{Overvlew:}

The company services only the waste management needs of the Babcock and Wilcox (B\&W) company's Naval Nuclear Fuel Division.

\section{Current Capabilities:}

The company provides storage for B\&W-generated LLRW and LMW. Volume reduction is performed using super compaction methods. It treats $L M W$ using neutralization, micro-fittration, microwave separation, compaction, stabilization/solidification, distillation, and delisting techniques. Recovery of uranium product and scrap materials uses solvent extraction methods. Complete R\&D and test laboratories are used to develop new technologies as required by B\&W.

B\&W does not provide these services to other waste generators. However, $B \& W$ is willing to make its experience and knowledge available in support of DOE and DOE contractors in their waste management programs.

\section{Future Capabilities:}

B\&W has no specific plans to provide services to waste generators outside of the company.

\section{Permits and Licenses:}

The vendor did not provide detailed licensing and permitting information. 


\section{BARTLETT NUCLEAR INC.}

\begin{tabular}{|c|c|c|}
\hline phopto & $\begin{array}{l}\text { DiMascio, Nick } \\
(800) 225.0385 \\
(508) 746.6518\end{array}$ & $\begin{array}{l}60 \text { industrial Park Road } \\
\text { Plymouth industrial Park } \\
\text { Plymouth, MA } 02360\end{array}$ \\
\hline
\end{tabular}

\section{Services Provided:}

X Low-Level Radioactive Waste Volume Reduction

Low-Level Mixed Waste Treatment

Low-Level Alpha-Contaminated Mixed Waste

Low-Level Mixed Waste Treatability Studies

$X \quad$ Low-Level Radioactive Waste Decontamination/Recycling

Low-Level Mixed Waste Storage and Disposal

$X \quad$ Laundering of Radioactively-Contaminated Laundry and/or Respirators

\section{Overview:}

Bartlett Nuclear, Inc., and it's sister company Bartlett Services, Inc., provide health physics, decontamination, and decommissioning consultation and services to the commercial nuclear power industry and DOE and DOD facilities. Past health physics and decontamination experience includes providing personnel to 63 pressurized water reactors, 34 boiling water reactors power plants, and ten DOE facilities and numerous other radioactive material users.

\section{Current Capabilities:}

Bartiett can supply any of the services and equipment listed below. Bartlett is capable of designing and manufacturing specialized equipment for customer's needs.

Volume Reduction: Bartlett has a Mobile Waste MonitorNolume Reduction System, which is a selfcontained trailer designed to monitor all dry waste leaving a site. Clean waste is shredded into one-half inch pieces that are disposed of as clean trash. The waste monitor will detect $5000 \mathrm{dpm}$ above background levels assuming uniform distribution per 50 pound bag of waste. This measurement is at the 95 percent probability of detection.

Decontamination Senices: The Bartlett PlasBlast System utilized a high velocity stream of plastic particles (PlasTek) to decontaminate any surface. Plant components with critical dimensions and surfaces are easily decontaminated without impacting the integrity of the base material. The PlasTek particles do not remove or abrade the surface being cleaned and PlasTek is incinerable, which reduces waste volume. Bartlett Services can provide mobile tool and equipment decontamination trailers for outage support. Either glass bead or plastic systems, high-pressure water booths, or Ultrasonic tanks can be provided.

Decontamination of LRW Metals: Bartlett has developed a cleaning agent called BY*PAS Decontamination Chemical, which is approved for use at many reactor facilities. Bartlett's Sonatol Process uses an inert organic solvent and a carefully designed surfactant in an ultrasonic bath to remove loose and tightly adhered radioactive particles from surfaces. The Sonatol process also includes real time monitoring of the decontamination activity to optimize the process time for each batch of contaminated objects.

Laundry Services: Bartlett manufactures a Mobile Respirator Decontamination system which includes a complete wash line with deep sink, washer, HEPA vacuum, drying oven, and survey area; complete water reprocessing system with a 5 micron particulate filter, activated charcoal, and mixed bed resin system; and a 48 foot trailer with air conditioning, nuclear grade HEPA system, and HALON 1301 fire suppression system. The system provides automated controls for water temperature, water quality, drying cabinet 
temperature, water level, and flow rate. In addition Bartlett is a supplier of radiation protection and decontamination personnel. These personnel are experienced with DOE facilities and operations. All personnel qualifications are evaluated under the direction of a Certified Reactor Health Physicist with NRC experience.

\section{Future Capabilities:}

No information given on this survey.

\section{Permits and Licenses:}

Bartlett provides radiological equipment and supplies for use under facility licenses and permits. No offsite facilities are currently licensed for independent operation. 


\begin{tabular}{|c|c|c|}
\hline $\begin{array}{l}\text { gep: } \\
\text { Prone? }\end{array}$ & $\begin{array}{l}\text { Dam, A Scott, PE } \\
(703) \text { 385-7100 } \\
(703) 385-7128\end{array}$ & $\begin{array}{l}9302 \text { Lee Highway } \\
\text { Suite } 950 \\
\text { Fairfax, VA } 22031 \text { - } 1207\end{array}$ \\
\hline
\end{tabular}

\section{Services Provided:}

X Low-Level Radioactive Waste Volume Reduction

$X \quad$ Low-Level Mixed Waste Treatment

Low-Level Alpha-Contaminated Mixed Waste

Low-Level Mixed Waste Treatability Studies

$X \quad$ Low-Level Radioactive Waste Decontamination/Recycling

Low-Level Mixed Waste Storage and Disposal

Laundering of Radioactively-Contaminated Laundry and/or Respirators

\section{Overview:}

British Nuclear Fuels Limited, Inc. (BNFL) implements design, engineering, and operation of facilities that process, treat, and dispose of radioactive and mixed wastes. BNFL and Raytheon Engineers and Constructors, Inc. (Raytheon) are involved in the design, process configuration, and mockup of a radioactive/hazardous waste treatment facility at DOE's Hanford site at Richland, Washington. BNFL has offices in Denver, Colorado that can be reached at (303) 694-0700.

\section{Current Capabilities:}

BNFL has the resources to provide expertise in the design and engineering of radioactive waste facilities. Specific areas of expertise include waste treatment facility design and engineering for processing, treating, and disposing of radioactive wastes. New waste treatment and disposal technology development for radioactive wastes is ongoing.

\section{Future Capabilities:}

BNFL is currently designing, constructing, and operating radioactive and hazardous waste treatment, storage, and disposal operations in England. BNFL manufactures nuclear fuel, reprocesses spent fuel, transports fuel and wastes, decommissions facilities, and provides waste management at five facilities in the UK. These operations have been in use for several years and meet all government requirements. BNFL has developed the CACTTOX soil treatment process for removing heavy metals and radionuclides from soils in-situ. This technology is applicable to U.S. facilities. The teaming with Raytheon includes an expression of interest to transport and treat mixed radioactive/hazardous solid waste at the INEL.

\section{Permits and Licenses:}

Licensing and permitting information was not provided in the information from the vendor. 
COGNIS, INC.

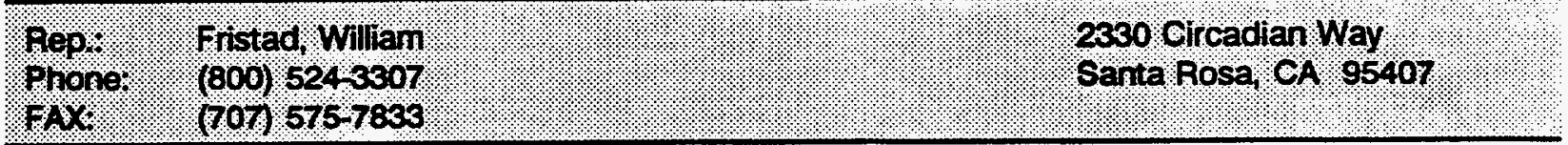

\title{
Services Provided:
}

\author{
Low-Level Radioactive Waste Volume Reduction \\ Low-Level Mixed Waste Treatment \\ Low-Level Alpha-Contaminated Mixed Waste \\ X Low-Level Mixed Waste Treatability Studies \\ Low-Level Radioactive Waste Decontamination/Recycling \\ Low-Level Mixed Waste Storage and Disposal \\ Laundering of Radioactively-Contaminated Laundry and/or Respirators
}

\section{Overview:}

COGNIS is a subsidiary of the Henkel Corporation. It is the parent company's research arm in metal separation technology. It is the first company to put a soil washing/soil leaching mobile plant in the field successfully. The company is interested in developing technologies for treating radioactive and mixed wastes.

\section{Current Capabilities:}

The company has developed and successfully employed a transportable soil treatment plant for heavy metals. It has the capability to treat excavated soil, return it on-site, and recycle the recovered metals.

\section{Future Capabilities:}

The company would like to apply its expertise in heavy metal recovery to LRW and/or LLMW treatment.

\section{Permits and Licenses:}

The company is fully permitted to handle RCRA and other heavy metal wastes. The company is also permitted by the state of California to receive, use, possess, transfer, or dispose of small quantities of specific radionuclides for use in labeling and as tracers in chemical and biological studies. 


\begin{tabular}{|c|c|c|}
\hline $\begin{array}{l}\text { nep: } \\
\text { Phone: } \\
\text { fext: }\end{array}$ & $\begin{array}{l}\text { Hembree, lanyll } \\
(615) 376.0084 \\
(615) \quad 376.0087\end{array}$ & $\begin{array}{l}\text { P.O. Box } 863 \\
\text { Kingston, TN } 37763\end{array}$ \\
\hline
\end{tabular}

\title{
Services Provided:
}

\author{
Low-Level Radioactive Waste Volume Reduction \\ $X \quad$ Low-Level Mixed Waste Treatment \\ X Low-Level Alpha-Contaminated Mixed Waste \\ Low-Level Mixed Waste Treatability Studies \\ X Low-Level Radioactive Waste Decontamination/Recycling \\ Low-Level Mixed Waste Storage and Disposal \\ Laundering of Radioactively-Contaminated Laundry and/or Respirators
}

\section{Overview:}

Diversified Scientific Services, Inc. (DSSI), a subsidiary of Chemical Waste Management, Inc., operates a mixed waste treatment facility. The facility employs an industrial boiler to combust solvents for generation of electricity. Other materials, such as containers that hold the flammable solvents, are aiso recycled for beneficial use.

\section{Current Capabilities:}

The DSSI facility treats hazardous liquid wastes through combustion. The facility can accept and recycle waste solvents in the D001, and F001 through F005 categories, D004 through D043 wastes, selected U-, and P-listed materials, and process any RCRA non-wastewaters and used oil. DSSI's radiological license allows the receipt of low-level liquid mixed wastes that contain some special nuclear material and source material.

\section{Future Capabllities:}

The burning capacity will be increased to meet future demands. There are no plans to increase the level of radionuclides in solvents accepted at the facility. Air pollution permit is under timely renewal with TDEC. Resource restrictions are delaying their re-issuance but they have indicated that a new permit would be forthcoming.

\section{Permits and Licenses:}

- Permits issued by the Tennessee Department of Health and Environment

- Radioactive Materials License No. R-730-14-K98, expires August 31, 1995

- TSD Part B-Hazardous Waste Permit No. TNHW-024, expires August 14, 1999

- $\quad$ Air Pollution Permit No. 937185F, expired January 1, 1994, in review with State

- EPA Generator No. TW098-210-9142

- NPDES Storm Water Runoff Permit No. TNR00321 issued by the Tennessee Department of Conservation, expires September 26, 1997 
- Permits issued by the USEPA, Region NV

- NESHAP Permit, no expiration

- Boiler and Industrial Furnace (BIF) Part B Permit, Part A, in interim status

- Small Power Production Facility FERC Permit Docket No. QF-89-280-000, no expiration, issued by the Federal Energy Regulatory Commission

- Nuclear Regulatory Commission permit expected to be approved by May 1995 


\begin{tabular}{|c|c|c|}
\hline $\begin{array}{l}\text { pep: } \\
\text { Phone: } \\
\text { FAx: }\end{array}$ & $\begin{array}{l}\text { Brunsell, Dennis } \\
(615) \quad 53990.00 \\
(615) \quad 5399001\end{array}$ & $\begin{array}{l}\text { Westbridge Business Park } \\
2860 \text { Westcott Bhd } \\
\text { Knoxville. TN } 37931\end{array}$ \\
\hline
\end{tabular}

\section{Services Provided:}

X Low-Level Radioactive Waste Volume Reduction

X Low-Level Mixed Waste Treatment

$X \quad$ Low-Level Alpha-Contaminated Mixed Waste

$X \quad$ Low-Level Mixed Waste Treatability Studies

Low-Level Radioactive Waste Decontamination/Recycling

Low-Level Mixed Waste Storage and Disposal

Laundering of Radioactively-Contaminated Laundry and/or Respirators

\section{Overview:}

Diversified Technologies (DT) is involved in filtration, demineralization, reverse osmosis, volume reduction, dewatering and drying, and polymer and vitrification solidification activities. DT provides on-site support to customers to support waste cleanup activities.

\section{Current Capabilities:}

DT can currently conduct treatability studies and solidify wastes using thermosetting polymers. DT has commercialized the use of reverse osmosis processes for volume reduction applications.

\section{Future Capablities:}

DT has a Mobile Treatment Unit (MTU) for sludge dewatering, drying, volume reduction and polymer solidification for treating $1,000 \mathrm{lbs} / \mathrm{hr}$ of solids. DT offers the use of thermosetting polymers for in-situ solidification of wastes and reverse osmosis processes for volume reduction of liquid wastes. DT will offer on-site waste treatment using self-contained, skid-mounted equipment.

\section{Permits and Licenses:}

DT has applied for NRC and RCRA license to perform treatability studies on radioactive and mixed wastes . All D- and F- listed wastes are accepted upon prior approval. 


\title{
DUKE ENGINEERING AND SERYICES
}

\begin{tabular}{|c|c|c|}
\hline Rop: & $\begin{array}{l}\text { Ratter, Mike } \\
(704) 382-1404 \\
(704) 382-8766\end{array}$ & $\begin{array}{l}230 \text { South Tryon Street } \\
\text { PO. Box } 1004 \\
\text { Charlotte, NC } 28201.1004\end{array}$ \\
\hline
\end{tabular}

\section{Services Provided:}

\author{
Low-Level Radioactive Waste Volume Reduction \\ Low-Level Mixed Waste Treatment \\ Low-Level Alpha-Contaminated Mixed Waste \\ X Low-Level Mixed Waste Treatability Studies \\ Low-Level Radioactive Waste Decontamination/Recycling \\ Low-Level Mixed Waste Storage and Disposal \\ Laundering of Radioactively-Contaminated Laundry and/or Respirators
}

Overview:

Duke Engineering and Services did not provide a company overview with the questionnaire for the 1994 survey.

\section{Current Capabilities:}

All current LLRW and LLMW activities are in support of Duke Power company-generated wastes. License restrictions allow only Duke Power company-generated wastes to be processed or studied.

\section{Future Capabilities:}

The company is interested in performing treatability studies for outside customers in the future when licensing becomes available.

Permits and Licenses:

Licenses are for Duke Power company-generated materials only. 


\begin{tabular}{|c|c|c|}
\hline $\begin{array}{l}\text { Rep: } \\
\text { Phone: } \\
\text { FAX: }\end{array}$ & $\begin{array}{l}\text { Fellows, Mark } \\
(334) 899.4351 \\
(334) 89992010\end{array}$ & $\begin{array}{l}\text { PO. Box } 409 \\
\text { Ashford, AL } 36312\end{array}$ \\
\hline
\end{tabular}

\section{Services Provided:}

Low-Level Radioactive Waste Volume Reduction Low-Level Mixed Waste Treatment Low-Level Alpha-Contaminated Mixed Waste Low-Level Mixed Waste Treatability Studies Low-Level Radioactive Waste Decontamination/Recycling Low-Level Mixed Waste Storage and Disposal

$X \quad$ Laundering of Radioactively-Contaminated Laundry and/or Respirators

\section{Overvlew:}

Eastern Technologies, Inc. (ETI) has been providing radiological laundry services to the nuclear industry since 1987. ETI operates a licensed off-site facility and provides mobile water wash laundry systems.

\section{Current Capablities:}

ETI presently operates a laundering facility for radioactively contaminated clothing and respirators in Ashford, Alabama. An aqueous-borne ozone cleaning system is used for cleaning of protective clothing, modesty garments and other launderable items (i.e., bath towels, mop heads, decon towels, etc.). ETI maintains separate equipment to process contaminated and non-contaminated items, to ensure that cross contamination does not occur. In addition to the Alabama facility, ETI provides mobile on-site water wash services. The mobile facility also utilizes the aqueous-borne ozone cleaning system. Two sizes of mobile units are available, rated at 1,400 and 2,400 sets per twenty-four hours. Services available with the mobile units include water wash processing of protective clothing, monitoring of processed clothing, repair of protective clothing, and cleaning and drying of respirators and related equipment (approximately 400 units per twenty-four hours). ETl's mobile system is comprised of three trailers ( 1 at $8^{\prime}$ by $45^{\prime}$ and 2 at $8^{\prime}$ by 53'). All laundry is monitored by an Automated Radioactive Laundy Monitor (ARLM). The monitor utilizes upper and lower overlapping high efficiency (<7000 dpm for most isotopes) gas flow proportional detectors to survey protective clothing items on all sides simultaneously.

\section{Future Capabilities:}

No information was given on this survey.

\section{Permits and Licenses:}

The ETI Ashford facility operates under a state radioactive materials license (Number: Alabama 947). 
ENVROCARE OF UTAH, INC.

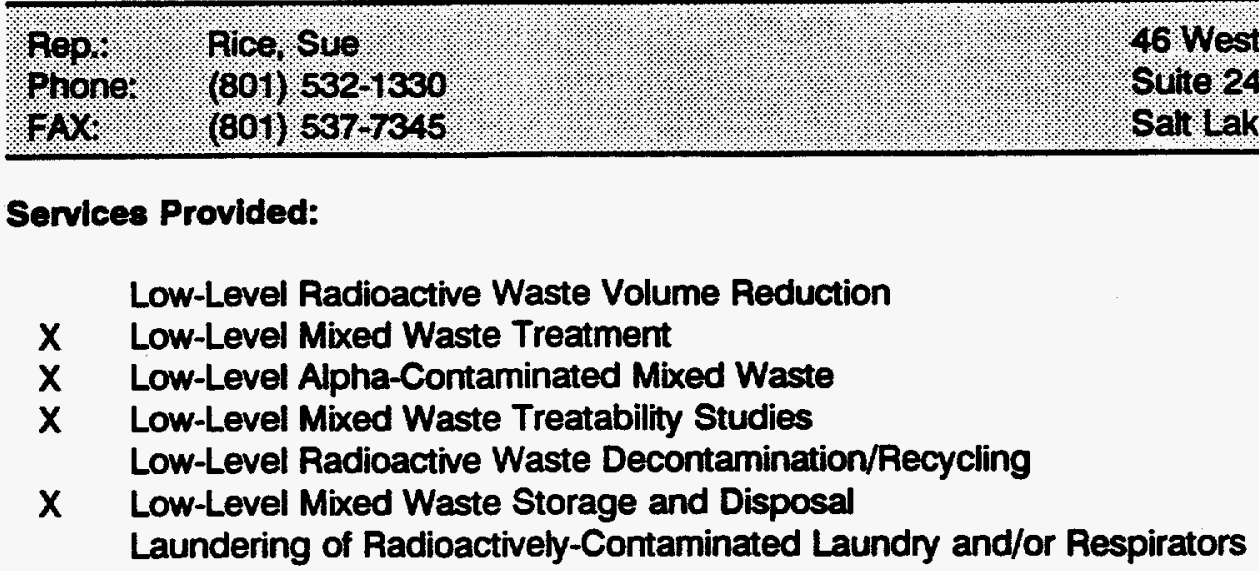

\section{Overview:}

Envirocare operates a waste disposal facility at Clive, Utah. The facility accepts and disposes of LRW and LLMW.

\section{Current Capabilities:}

Envirocare treats LLMW using chemical stabilization for concentration-based mixed waste to meet land disposal restrictions. Envirocare can conduct treatability studies. Envirocare does not accept pure liquids for solidification and disposal. However, wastes that are predominantly solid but do contain some free liquid can be treated and disposed at the facility.

\section{Future Capablities:}

The Envirocare treatment facility has been completed and is undergoing final inspection by the State of Utah. Treatment operations are scheduled to begin the week of $4 / 3 / 95$. This facility will employ chemical treatments to reduce waste extract concentrations of hazardous constituents prior to disposal.

A RCRA Part B modification addressing lead encapsulation has been submitted to the appropriate regulatory body. Availability of this technology is anticipated to be in mid-September 1995.

\section{Permits and Licenses:}

Radioactive Material License, UT 2300249 issued by the Utah Division of Radiation Control

RCRA Part B Permit, Utah Division of Solid and Hazardous Waste, expires November 30, 2000 


\begin{tabular}{|c|c|c|}
\hline $\begin{array}{l}\text { Repl } \\
\text { Phone: } \\
\text { FAX: }\end{array}$ & $\begin{array}{l}\text { (Hodin Lamy } \\
(702) 871-1884 \\
(702) 8713529\end{array}$ & $\begin{array}{l}1335 \text { W. Tropicana } \\
\text { Suite } 3 \\
\text { Las Vegas, NV } 89103 \text {. }\end{array}$ \\
\hline
\end{tabular}

\title{
Services Provided:
}

\author{
Low-Level Radioactive Waste Volume Reduction \\ $X \quad$ Low-Level Mixed Waste Treatment \\ $X \quad$ Low-Level Alpha-Contaminated Mixed Waste \\ $X \quad$ Low-Level Mixed Waste Treatability Studies \\ Low-Level Radioactive Waste Decontamination/Recycling \\ Low-Level Mixed Waste Storage and Disposal \\ Laundering of Radioactively-Contaminated Laundry and/or Respirators
}

\section{Overview:}

Fluid Tech performs treatability studies on $\amalg R W$ and $U M W$.

\section{Current Capabilities:}

Fluid Tech performs treatability studies for solidification of LRW and chemical stabilization of hazardous constituents of LLMW. Fluid Tech has a licensed treatability lab for handling LLRW and LLMW samples.

\section{Future Capabilities:}

Fluid Tech develops new formulations for the treatment of LLRW and LLMW as an ongoing part of the company business.

\section{Permits and Licenses:}

Fluid Tech has a license for low-level radioactive waste handling (listed below).

Hazardous constituents/EPA Waste Codes accepted: None

Radionuclides accepted and associated license limits: Uranium, Thorium, Barium, Cesium, Depleted Uranium, Mixed Fission Products, Enriched Uranium; Limited to 1.85 millicuries total on site at Laboratory at one time.

NRC License \# 03-11-0339-01, expires February 28, 1999 
HAZEN RESEARCH, INC.

nep. 19 . Downey, lem

Phone. 1 (303) 2794501

$\mathrm{FAX}$.

\section{Services Provided:}

Low-Level Radioactive Waste Volume Reduction

Low-Level Mixed Waste Treatment

Low-Level Alpha-Contaminated Mixed Waste

$x \quad$ Low-Level Mixed Waste Treatability Studies

Low-Level Radioactive Waste Decontamination/Recycling

Low-Level Mixed Waste Storage and Disposal

Laundering of Radioactively-Contaminated Laundry and/or Respirators

\section{Overview:}

Hazen is a consulting and research company providing research and development services to a wide range of customers in the mining, water treatment, and waste management industries.

\section{Current Capabillties:}

Hazen performs a wide range of research studies in the treatability of wastes. Hazen has the staff and facilities to perform studies on the treatment of LRW and LMW wastes.

Future Capabilitles:

No information was provided.

\section{Permits and Licenses:}

- State of Colorado, Department of Public Health, Radioactive Materials License No. 77-02, expired September 30, 1994. (Note: Hazen will continue to operate under this license while the State processes renewal application.)

Radionuclides accepted and associated license limits: Any radionuclide with atomic number 1 through 96. The maximum quantity that Hazen may posses at one time for treatability studies is limited to 10 microcuries.

- $\quad$ EPA letter of approval dated July 27, 1994 to perform research on various hazardous materials; expiration date June 24, 1995

Hazardous constituents/EPA Waste Codes accepted: Under certain restrictions, Hazen can accept all EPA Waste Codes. P-listed wastes are subject to a 1 kilogram lifetime restriction. For other waste codes, Hazen can accept and study up to 10,000 kilogram of contaminated soil or up to 1,000 kilograms of pure waste.

Hazen is authorized by the Colorado Department of Health to conduct treatability studies on samples of waste which are listed and/or characteristic hazardous wastes at their site of origin. Such studies are permitted under the condition of Colorado regulations 1007-3 CCR (e) and (f) governing treatability studies.

IC TECHNOLOGIES, INC. 
Services Provided:

\author{
Low-Level Radioactive Waste Volume Reduction \\ Low-Level Mixed Waste Treatment \\ Low-Level Alpha-Contaminated Mixed Waste \\ X Low-Level Mixed Waste Treatability Studies \\ Low-Level Radioactive Waste Decontamination/Recycling \\ Low-Level Mixed Waste Storage and Disposal \\ Laundering of Radioactively-Contaminated Laundry and/or Respirators
}

\title{
Overview:
}

IC Technologies, Inc. (ICT) is a consulting and service-based company providing services to the environmental, mineral, chemical, and manufacturing industry. The only information ICT provided was the questionnaire in 1994; no other company information was included in the response.

\section{Current Capabilities:}

ICT performs LLMW treatability studies on several types of wastes, including LLRW and LLMW.

\section{Future Capabllties:}

No information on ICT's future plans was included on the questionnaire.

\section{Permits and Licenses:}

- RCRA Permit No. 983796343 for metals, solvents, and organics

Hazardous constituents/EPA Waste Codes accepted: All constituents for treatability on advance notice

Colorado State Radioactive Materials License No. 701-02; expires April 30, 1996, for small quantities of low activity waste

Radionuclides accepted and associated license limits: $U$ (nat), $60 \mathrm{mCi}$ U(depl), $10 \mathrm{mCi}$; Th(nat), $15 \mathrm{mCi}$; Pu-239/240, $1 \mathrm{mCi}$; AM-241, $1 \mathrm{mCi}$; Sr-90, $1 \mathrm{mCi}$; Cs-137, $1 \mathrm{mCi}$; H-3, $10 \mathrm{mCi}$; and Ra-226, $0.1 \mathrm{mCi}$ 
INTERNATIONAL TECHNOLOGY CORPORATION

\begin{tabular}{|c|c|c|}
\hline $\begin{array}{l}\text { Rep. } \\
\text { phone? } \\
\text { Fox }\end{array}$ & $\begin{array}{l}\text { Aperin, Ed } \\
(615) 6903211 \\
(615) 6903626\end{array}$ & 304, Directors Brive \\
\hline
\end{tabular}

\section{Services Provided:}

Low-Level Radioactive Waste Volume Reduction

Low-Level Mixed Waste Treatment

Low-Level Alpha-Contaminated Mixed Waste

X Low-Level Mixed Waste Treatability Studies

Low-Level Radioactive Waste Decontamination/Recycling

Low-Level Mixed Waste Storage and Disposal

Laundering of Radioactively-Contaminated Laundry and/or Respirators

\section{Overview:}

The International Technology Corporation (IT) Development Laboratory and the Environmental Technology Development Center are licensed to conduct treatability studies on radioactive and mixed wastes.

\section{Current Capabilities:}

IT conducts treatability studies of LLRW and LUMW. Methods studied include stabilization, vitrification, thermal desorption, incineration, oxidation, wet oxidation, high-pressure wet oxidation, soil washing, chemical extraction, absorption, and ion exchange.

\section{Future Capabilities:}

The information provided did not include information on future plans of the company.

Permits and Licenses:

- State of Tennessee Radioactive Materials License Nos. R-01060-J95 and R-47055-D98 issued by the Tennessee Department of Health and Environment, Division of Radiological Health 


\section{INTERSTATE NUCLEAR SERVICES CORPORATION}

\begin{tabular}{|c|c|c|}
\hline $\begin{array}{l}\text { Rep: } \\
\text { Phone: } \\
\text { fox }\end{array}$ & $\begin{array}{l}\text { Crusselle, vick } \\
(413) 5432975 \\
(413) 5432975\end{array}$ & $\begin{array}{l}\text { 295 Parker Street } \\
\text { P. O Box } 51957 \\
\text { Springfield, MA } 01151\end{array}$ \\
\hline
\end{tabular}

\section{Services Provided:}

Low-Level Radioactive Waste Volume Reduction

Low-Level Mixed Waste Treatment

Low-Level Alpha-Contaminated Mixed Waste

Low-Level Mixed Waste Treatability Studies

$X$ Low-Level Radioactive Waste Decontamination/Recycling

Low-Level Mixed Waste Storage and Disposal

$X \quad$ Laundering of Radioactively-Contaminated Laundry and/or Respirators

\section{Overview:}

Interstate Nuclear Services Corporation (INS) has been a supplier of radiological laundry and protective clothing programs since 1957. INS services $80 \%$ of the commercial nuclear industry, $100 \%$ of the Naval Shipyards and many DOE and private facilities from a network of 14 strategically located facilities. Protective clothing and equipment sales and leasing is also available through INS. INS currently provides laundry service to the INEL

\section{Current Capabilities:}

Laundry Senvices: INS presently operates 14 different laundering facilities. The typical wash capacity at INS facilities is approximately 2,000 pounds per hour. The Hanford facility is the largest INS facility, cleaning up to 3,500 pounds per hour. INS facilities provide protective wear decontamination, respirator decontamination, and recertification. Five models of laundry monitors are in use at INS facilities. Each one has been designed for a specific application (low-level contamination monitoring, alpha monitoring, large area monitoring, hot particle monitoring, etc.). INS also provides on-site mobile water wash units capable of processing $\mathbf{3 5 0}$ pounds per hour; respirator cleaning, inspection and recertification, and respirator filter cartridge testing and recertification. All respirator work is performed in compliance with NUREG 0041.

Decontamination of LLRW Metals: INS provides on-site mobile metal decontamination units which employ state of the art cleaning methods for metals recovery and waste reduction.

Future Capablitities:

INS has been awarded a long-term contract to provide protective wear laundry and respirator decontamination services to the DOE Savannah River Site (SRS). Services will be provided from a new laundry facility to be built by INS near the SRS, with operation to begin in 1996.

\section{Permits and Licenses:}

The Hanford facility in Richland Washington operates under a state radioactive materials license (Number WN-10414-1). 
NON-DESTRUCTIVE CLEANING, INC.

\begin{tabular}{|c|c|c|c|}
\hline $\begin{array}{l}\text { gep. } \\
\text { phone? } \\
\text { Fox }\end{array}$ & $\begin{array}{l}\text { Dufal, Keith } \\
(818), 761.0264 \\
(818) 7615980\end{array}$ & $\begin{array}{l}\text { 4944 Cahuenga Blvd. } \\
\text { North Hollyood, CA }\end{array}$ & 91601 \\
\hline
\end{tabular}

\title{
Services Provided:
}

\author{
Low-Level Radioactive Waste Volume Reduction \\ Low-Level Mixed Waste Treatment \\ Low-Level Alpha-Contaminated Mixed Waste \\ Low-Level Mixed Waste Treatability Studies \\ X Low-Level Radioactive Waste Decontamination/Recycling \\ Low-Level Mixed Waste Storage and Disposal \\ Laundering of Radioactively-Contaminated Laundry and/or Respirators
}

\section{Overview:}

Non-Destructive Cleaning, Inc. (NDC) designs and builds dry ice $\left(\mathrm{CO}_{2}\right)$ decontamination systems for sale or lease according to the customers' needs.

\section{Current Capabilities:}

NDC's dry ice systems leave no residue and no secondary contamination, such as water or spent grit, requiring disposal. The systems are mobile units allowing on-site decontamination for users.

\section{Future Capabillties:}

The information provided did not include future plans of the company.

Permits and Licenses:

No permits or licenses are necessary. The vendor operates under its clients' facility permits and licenses. 
NUCLEAR FUEL SERVICES, INC.

\begin{tabular}{|c|c|c|}
\hline $\begin{array}{l}\text { Rop? } \\
\text { Phone: } \\
\text { FAx: }\end{array}$ & $\begin{array}{l}\text { Claik, RD } \\
(615) 743-1706 \\
(615) 743.0140\end{array}$ & $\begin{array}{l}1205 \text { Banner Hil Road } \\
\text { Envin, TN } 37650\end{array}$ \\
\hline
\end{tabular}

Services Provided:

$\begin{array}{ll}\text { X } & \text { Low-Level Radioactive Waste Volume Reduction } \\ \text { X } & \text { Low-Level Mixed Waste Treatment } \\ \text { X Low-Level Alpha-Contaminated Mixed Waste } \\ \text { X Low-Level Mixed Waste Treatability Studies } \\ \text { X Low-Level Radioactive Waste Decontamination/Recycling } \\ \text { X Laundering of Radioactively-Contaminated Laundry and/or Respirators }\end{array}$

Overview:

Nuclear Fuel Services, Inc. (NFS), a subsidiary of NFS Services, Ltd., provides advanced technical services and systems to both government and commercial clients. NFS' primary categories of expertise include decontamination and decommissioning (D\&D), environmental remediation, waste treatment and disposition, and processing of special nuclear materials. Radioactive materials expertise includes uranium, plutonium and thorium. D\&D services include site decommissioning, decontamination and volume reduction, and waste packaging and disposition of uranium, plutonium, or thorium contaminated systems. Environmental remediation services include sampling, analysis, packaging and transport of waste, and bench and pilot scale treatability studies. Waste treatment and disposition capabilities encompass the treatment of nuclear, hazardous and mixed waste, and the treatment of soil, sludge and wastewater. The company also has the capability to process several types of special nuclear materials such as high- and low-enriched uranium and to perform resource and scrap recovery.

\section{Current Capabilities:}

The company has a recovery and purification throughput capacity of 2500 to $5000 \mathrm{~kg} \mathrm{U} / \mathrm{yr}$ of HEU and up to $50,000 \mathrm{~kg} \mathrm{U} / \mathrm{yr}$ of purified uranyl nitrate. NFS is permitted by the state of Tennessee to accept up to $10,000 \mathrm{~kg}$ of mixed waste for treatability testing. The company has development and engineering facilities for researching and evaluating remediation processes for treating radioactive and mixed wastes (including $\mathrm{U}, \mathrm{Pu}$, and $\mathrm{Th}$ ), minimizing waste, and resource recovery. The company also provides analytical laboratory services. NFS also maintains a 25,000 square foot laboratory in Atlanta, Georgia which has the capability of analyzing hazardous and inorganic materials and performing radiochemical analyses.

\section{Future Capabilities:}

NFS is planning to apply for a RCRA permit for a proprietary process to treat LLMW within the next five years.

\section{Permits and Licenses:}

- Special Nuclear Materials License No. SNM-124 from the Nuclear Regulatory Commission

- Radioactive Source Material License No. S-860001 from the State of Tennessee

- Radioactive Byproduct Material License No. R-860002-S93 from the State of Tennessee

- EPA RCRA Permit No. TNHW-066 from the State of Tennessee 
- Authorized possession and processing of up to $7,000 \mathrm{~kg} \mathrm{of}{ }^{235} \mathrm{U}$ (fully enriched)

- NRC licensed process for enrichment blend down of weapons grade uranium to commercial enrichment 


\begin{tabular}{|c|c|c|}
\hline $100 \%$ & $\begin{array}{l}\text { Lehan, Dennis } 1 \text { ? } \\
(508) \text {. } 369-5410 \\
(508) \quad 5683694045\end{array}$ & Concord $\mathrm{MA}$. 01742 \\
\hline
\end{tabular}

\section{Services Provided:}

X Low-Level Radioactive Waste Volume Reduction

X Low-Level Mixed Waste Treatment Low-Level Alpha-Contaminated Mixed Waste

$X \quad$ Low-Level Mixed Waste Treatability Studies

$X \quad$ Low-Level Radioactive Waste Decontamination/Recycling

$X \quad$ Low-Level Mixed Waste Storage and Disposal Laundering of Radioactively-Contaminated Laundry and/or Respirators

\section{Overview:}

Nuclear Metals, Inc. (NMI) is a storage and treatment company for LLRW and LLMW. NMI uses various volume reduction processes to reduce the volume of LLRW and LLMW.

\section{Current Capabllities:}

NMI is treating and storing LLRW and LLMW using processes developed in house and other industrial methods. NMI has developed the Hydromet process, Denver process, ring mill pulverizer chip compaction process, and HEPA fitter process to treat wastes. NMI uses a high-pressure water jet technique, as well as other abrasive methods, to decontaminate metals for reuse, recycling, or release. NMI uses processes developed in house to process and recover LRW. NMI develops bench and pilot-scale treatability studies for LLRW and LLMW.

\section{Future Capabilities:}

NMI has installed a metal melting facility at Carolina Metals to melt, cast, and process various metals exhibiting radioactive contamination.

\section{Permits and Licenses:}

NMI stated that they were licensed by the NRC or an agreement state to treat or store LLRW and LLMW. No details on the licenses were supplied. NMI is planning to apply for a RCRA permit for their Depleted Uranium Recycle Facility, located at Barnwell, South Carolina. 


\begin{tabular}{|c|c|c|}
\hline $\begin{array}{l}\text { gep } \\
\text { phone: } \\
\text { ENX: }\end{array}$ & $\begin{array}{l}\text { Byrd, Butch } \\
(800), 3930222 \\
407) 834.4559\end{array}$ & 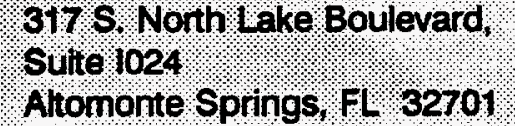 \\
\hline
\end{tabular}

Services Provided:
Low-Level Radioactive Waste Volume Reduction
Low-Level Mixed Waste Treatment
Low-Level Alpha-Contaminated Mixed Waste
Low-Level Mixed Waste Treatability Studies
Low-Level Radioactive Waste Decontamination/Recycling
Low-Level Mixed Waste Storage and Disposal
$X \quad$ Laundering of Radioactively-Contaminated Laundry and/or Respirators

\section{Overview:}

Octagon/Power Systems Energy Services, Inc. (PSESI) provides mobile wet laundering services for the commercial nuclear industry.

\section{Current Capabilities:}

Laundr Services: PSESI has developed a complete mobile wet laundry system. The system can be assembled at any location on a temporary or permanent foundation. The system occupies an area of approximately 30 feet by 48 feet and includes facilities for washing, drying, folding, and repair of protective clothing as well as respirator servicing. The facility provides HEPA filtration and water treatment for all process effluents. An optional shipping and receiving shelter can be added to the system to provide a fully covered laundry facility.

\section{Future Capablittles:}

No information given on survey.

\section{Permits and Licenses:}

PSESI services are provided under the authority of facility licenses and permits. PSESI does not currently maintain any licensed laundering facilities. 
RUST FEDERAL SERVICES, INC.

CLEMSON TECHNICAL CENTER

\begin{tabular}{|c|c|c|}
\hline $\begin{array}{l}\text { Rep: } \\
\text { Phone: } \\
\text { FAx: }\end{array}$ & $\begin{array}{l}\text { Ayen, Dick } \\
(803) 646-2413 \\
(803) 646-531\end{array}$ & $\begin{array}{l}100 \text { Technology Bive } \\
\text { Anderson, SC } 29625\end{array}$ \\
\hline
\end{tabular}

\title{
Services Provided:
}

\author{
Low-Level Radioactive Waste Volume Reduction \\ $X \quad$ Low-Level Mixed Waste Treatment \\ Low-Level Alpha-Contaminated Mixed Waste \\ X Low-Level Mixed Waste Treatability Studies \\ $X \quad$ Low-Level Radioactive Waste Decontamination/Recycling \\ $X$ Low-Level Mixed Waste Storage and Disposal \\ Laundering of Radioactively-Contaminated Laundry and/or Respirators
}

\section{Overview:}

RUST Federal Services provides a well-staffed technology center supporting a wide range of research and development activities. Bench-scale studies for waste stabilization and pilot plant demonstration and development are supported using RUST-developed methods as well as industry techniques.

\section{Current Capabilities:}

Perform treatability studies on treatment of radioactive and mixed wastes. Technologies studied include low-temperature thermal separation, incineration, sludge dryers, in-situ stabilization, phosphate-based stabilization, and biological treatments.

Future Capabilities:

An enhanced vitrification treatability study capability will be in place by late 1995.

\section{Permits and Licenses:}

- NRC licenses for research activities

- RCRA treatability exclusion; South Carolina has adopted new, very generous federal limits

- Several TSCA permits for treatment of PCBs

- Hazardous constituents/EPA Waste Codes accepted: No regulatory limits on which waste codes are accepted. Prior approval by RUST required before shipping. RUST operates under the quantity restraints of the EPA and SCDHEC treatability exclusion regulations and TSCA regulations. 
- Radionuclides accepted and associated license limits: (See below)

\begin{tabular}{|c|c|c|}
\hline $\begin{array}{l}\text { Radioactive Material } \\
\text { (Element and Mass Number) }\end{array}$ & $\begin{array}{l}\text { Chemical and/or } \\
\text { Physical Form }\end{array}$ & $\begin{array}{l}\text { Maximum Radioactivity and/or } \\
\text { quantity of material which } \\
\text { licensee may possess at any } \\
\text { one time }\end{array}$ \\
\hline $\begin{array}{l}\text { A. Any radioactive material } \\
\text { with Atomic Numbers } 2 \\
\text { through } 92 \text {. }\end{array}$ & A. Any & A. 2 curies. \\
\hline $\begin{array}{l}\text { B. Any radioactive material } \\
\text { with Atomic Numbers } 93 \text { and } \\
\text { above. }\end{array}$ & B. Any & B. 100 millicuries. \\
\hline C. Hydrogen-3 & C. Any & C. 10 curies. \\
\hline D. Source Material & D. Any & D. 1000 pounds. \\
\hline E. Special Nuclear Material & E. Any & $\begin{array}{l}\text { E. } 350 \text { grams of U-235, } 200 \\
\text { grams of U-233, } 200 \text { grams of } \\
\text { Plutonium, or any combination } \\
\text { where total grams of } U- \\
235 / 350 \text { and total grams } U \text { - } \\
233 / 200 \text { and total grams of } \\
\text { Plutonium/200 is less than or } \\
\text { equal to one. }\end{array}$ \\
\hline F. Nickel-63 & $\begin{array}{l}\text { F. Sealed source (Hewlett } \\
\text { Packard Model G1223A) }\end{array}$ & $\begin{array}{l}\text { F. No single source to exceed } \\
15 \text { millicuries. }\end{array}$ \\
\hline G. Nickel- 63 & $\begin{array}{l}\text { G. Sealed source (Hewlett } \\
\text { Packard Model 19233) }\end{array}$ & $\begin{array}{l}\text { G. No single source to } \\
\text { exceed } 15 \text { millicuries. }\end{array}$ \\
\hline H. Nickel-63 & $\begin{array}{l}\text { H. Sealed source (Perkin } \\
\text { Elmer Model N6000204) }\end{array}$ & $\begin{array}{l}\text { H. No single source to } \\
\text { exceed } 15 \text { millicuries. }\end{array}$ \\
\hline
\end{tabular}

Authorized State License/Permit \#482 (South Carolina Department of Health and Environmental Control Radioactive Material License), expiration date April 30, 1997 
SCIENTIFIC ECOLOGY GROUP, INC.

\begin{tabular}{|c|c|c|}
\hline 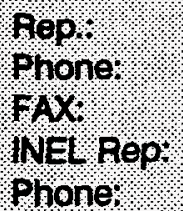 & $\begin{array}{l}\text { Smin Andy } \\
(615) 4810222 \\
(615) 4827206 \\
\text { Colleen Owens. } \\
(208) \text { ) } 528.6658 .\end{array}$ & $\begin{array}{l}\text { PO. Box } 2530 \\
1560 \text { Bear Creek Road } \\
\text { Oak Ridge, TN } 37830 \\
1470 \text { N Skyline } \\
\text { Idaho Falls, ID } 83402\end{array}$ \\
\hline
\end{tabular}

\title{
Services Provided:
}

\author{
X Low-Level Radioactive Waste Volume Reduction \\ $X \quad$ Low-Level Mixed Waste Treatment \\ $X \quad$ Low-Level Alpha-Contaminated Mixed Waste \\ $X \quad$ Low-Level Mixed Waste Treatability Studies \\ $X \quad$ Low-Level Radioactive Waste Decontamination/Recycling \\ Low-Level Mixed Waste Storage and Disposal \\ Laundering of Radioactively-Contaminated Laundry and/or Respirators
}

\section{Overview:}

Scientific Ecology Group, Inc. (SEG), a wholly owned subsidiary of Westinghouse, provides radioactive waste processing and management services. These services include metal processing, volume reduction of various waste forms, liquid disposal, and packaging,

\section{Current Capablities:}

SEG achieves volume reduction of solid and liquid (oil) wastes by incineration. SEG provides supercompaction services to reduce the volume of drums and boxes.

Liquid wastes are dewatered using vacuum compression dewatering of powdered and ion-exchange media. Liquids, sludges, resins and concentrates are processed by techniques designed for each waste type.

LLRW-contaminated metals are decontaminated using high-pressure water, steel shot, or glass bead blasting. Contaminated metals are melted down and poured into molds to form shieiding blocks.

LLMW will be treated by vitrification, molten metal solvent system, Synthetica, or solidification processes when RCRA permitting has been obtained. The process selected will depend on the waste constituents and the permits.

SEG can perform LLMW treatability studies in its laboratories. It has performed stabilization and vitrification testing on a variety of mixed wastes.

\section{Future Capablities:}

SEG has applied for a RCRA Part B Permit to allow processing of mixed wastes on a large scale. Several new mixed waste treatment technologies are being tested for use after permitting. SEG is currently purchasing land and planning to build a waste processing facility in Hanford, Washington. 


\section{Permits and Llcenses:}

- Four radioactive facility licenses for four operating facilities in Oak Ridge

- NRC license for their shipping casks

- A RCRA Part B permit applied for and pending for the Oak Ridge facilities; SEG expects approval of the Part B permit by the third quarter of 1995 


\section{U.S. ECOLOGY}

\begin{tabular}{|c|c|c|}
\hline $\begin{array}{l}\text { hep: } \\
\text { Phone? }\end{array}$ & $\begin{array}{l}\text { Gardner, Fredrick } \\
800-5672372 \\
(615) \text { (182 } 5605 .\end{array}$ & $\begin{array}{l}5333 \text { Westheimer } \\
\text { Suite } 1000 \\
\text { Houston, TX } 770.56-5407\end{array}$ \\
\hline
\end{tabular}

\section{Services Provided:}

X Low-Level Radioactive Waste Volume Reduction

$X \quad$ Low-Level Mixed Waste Treatment Low-Level Alpha-Contaminated Mixed Waste Low-Level Mixed Waste Treatability Studies

$X \quad$ Low-Level Radioactive Waste Decontamination/Recycling Low-Level Mixed Waste Storage and Disposal Laundering of Radioactively-Contaminated Laundry and/or Respirators

\section{Overview:}

U.S. Ecology, a subsidiary of American Ecology, operates a LRW disposal facility for institutional clients at Richland, Washington. No other information was provided on the questionnaire in the 1994 survey.

\section{Current Capabilities:}

U.S. Ecology provides volume reduction services for URW and decontaminates LLRW for metals reuse, recycling and/or free release. These services are limited to institutional clients, hospitals, and universities.

\section{Future Capabilities:}

U.S. Ecology is planning to apply for a RCRA permit for the thermal treatment of LLMW.

\section{Permits and Licenses:}

- Radioactive Materials License issued by State of California

- Radioactive Materials License is expected to be obtained for State of Nebraska in 1995 


\section{APPENDIX D}

Vendor Radioactive Material License Limit Profile

D-1 
Appendix D VENDOR RADIOACTIVE MATERIAL LICENSE LIMIT PROFILE'

\begin{tabular}{|c|c|c|c|c|c|c|c|c|c|c|c|}
\hline & ARS & $\begin{array}{l}\text { ALARON } \\
\text { Corp. }\end{array}$ & AEC & $\begin{array}{l}\text { COGNI } \\
\text { S, Ine. }\end{array}$ & $\begin{array}{l}\text { Envirocare } \\
\text {, Inc. }\end{array}$ & FTI & Hazen & ICT & $\pi$ & RUST & SEG $^{13}$ \\
\hline $\begin{array}{l}\text { Expiratio } \\
n \text { Date }\end{array}$ & $4 / 30 / 97$ & $\begin{array}{c}8 / 31 / 90 \\
\text { extende } \\
d\end{array}$ & $10 / 31 / 95$ & $\begin{array}{c}\text { 1/9/94 } \\
\text { extende } \\
d\end{array}$ & 2/28/96 & 2/28/99 & 9/30/94 & 4/30/96 & 4/30/98 & $4 / 30 / 97$ & $\begin{array}{c}\text { Renewals } \\
\text { Submitte } \\
\quad d\end{array}$ \\
\hline $\mathrm{Ag}-110 \mathrm{~m}$ & & & & & $560 \mathrm{pCV} / \mathrm{g}$ & & & & & & \\
\hline Am-241 & & & $1 \mathrm{Ci}$ & & $560 \mathrm{pCi} / \mathrm{g}$ & & & $1 \mathrm{mCi}$ & & & $250 \mathrm{Ci}$ \\
\hline Am-242 & & & $1 \mathrm{Ci}$ & & & & & & & & \\
\hline Am-243 & & & & & $1700 \mathrm{pCi} / \mathrm{g}$ & & & & & & \\
\hline $\mathrm{Ba}$ & & & & & & $1.85 \mathrm{mCi}$ & & & & & \\
\hline $\mathrm{Be}-7$ & & & & & $38 \mathrm{nCi} / \mathrm{g}$ & & & & & & \\
\hline$C_{-14}$ & & & $50 \mathrm{Ci}$ & $2 \mathrm{mCi}$ & $400 \mathrm{nCi} / \mathrm{g}$ & & & & & & $110 C i$ \\
\hline $\mathrm{Ca}-45$ & & & & $15 \mathrm{mCi}$ & $.4 \mathrm{mCl} / \mathrm{g}$ & & & & & & \\
\hline$C d-109$ & & & & & $460 \mathrm{nCi} / \mathrm{g}$ & & & & & & \\
\hline $\mathrm{Cm}_{\mathrm{m}-242}$ & & & $1 \mathrm{Ci}$ & & $1400 \mathrm{nCi} / \mathrm{g}$ & & & & & & \\
\hline $\mathrm{Cm}-243$ & & & $1 \mathrm{Ci}$ & & $1.5 \mathrm{nCi} / \mathrm{g}$ & & & & & & \\
\hline $\mathrm{Cm}-244$ & & & $1 \mathrm{Ci}$ & & $10 \mathrm{nCi} / \mathrm{g}$ & & & & & & \\
\hline Co-56 & & & & & $360 \mathrm{pCi} / \mathrm{g}$ & & & & & & \\
\hline Co-57 & & & & & $19 \mathrm{nCi} / \mathrm{g}$ & & & & & & \\
\hline Co-58 & $100 \mathrm{mCi}$ & & & & $1.6 \mathrm{nCi}$ & & & & & & \\
\hline Co-60 & $100 \mathrm{mCi}$ & & & & $360 \mathrm{pCi} / \mathrm{g}$ & & & & & & \\
\hline Cr-51 & & & & & $68 \mathrm{nCl} / \mathrm{g}$ & & & & & & \\
\hline Cs-134 & $100 \mathrm{mCi}$ & & & & $1.2 \mathrm{nCi} / \mathrm{g}$ & $1.85 \mathrm{mCi}$ & & & & & \\
\hline Cs-137 & $100 \mathrm{mCi}$ & & $1.2 \mathrm{Ci}$ & & $560 \mathrm{pCi} / \mathrm{g}$ & & & $1 \mathrm{mCi}$ & & & \\
\hline $\begin{array}{c}\text { D-38 } \\
\text { Th-232 } \\
\end{array}$ & $1000 \mathrm{~kg}$ & & $10 \mathrm{Ci}$ & & & & & & & & \\
\hline $\begin{array}{c}\text { Eu-152, } \\
-154,- \\
155 \\
\end{array}$ & $100 \mathrm{mCi}$ & & & & $1.7 \mathrm{nCi} / \mathrm{g}$ & & & & & & \\
\hline $\mathrm{Fe}-55$ & & & & & $.018 \mathrm{mCi} / \mathrm{g}$ & & & & & & \\
\hline Fm-257 & & & $1 \mathrm{Ci}$ & & & & & & & & \\
\hline $\mathrm{H}-3$ & $2 \mathrm{Ci}$ & & $100 \mathrm{Ci}$ & $2 \mathrm{mCi}$ & $.02 \mathrm{mCi} / \mathrm{g}$ & & & $10 \mathrm{mCi}$ & $10 \mathrm{Ci}$ & $10 \mathrm{Ci}$ & $330 \mathrm{Ci}$ \\
\hline $\mathrm{Hg}-203$ & & & & & 10nCi/g & & & & & & \\
\hline $1-129$ & $100 \mathrm{mCi}$ & & & & $3.1 \mathrm{nCi} / \mathrm{g}$ & & & & & & \\
\hline $\mid r-192$ & & & & & $2.5 \mathrm{nCi}$ & & & & & & \\
\hline$K-40$ & & & & & $10 \mathrm{nCl} / \mathrm{g}$ & & & & & & \\
\hline
\end{tabular}


Appendix D VENDOR RADIOACTIVE MATERIAL LCENSE LIMIT PROFILE ${ }^{1}$

\begin{tabular}{|c|c|c|c|c|c|c|c|c|c|c|c|}
\hline & ARS & $\begin{array}{l}\text { ALARON } \\
\text { Corp. }\end{array}$ & AEC & $\begin{array}{l}\text { COGNI } \\
\text { S, Inc. }\end{array}$ & $\begin{array}{l}\text { Emvirocare } \\
\text {, Inc. }\end{array}$ & FTI & Hazen & ICT & $\pi$ & RUST & SEG $^{13}$ \\
\hline MAFP $^{2}$ & $\begin{array}{c}10 \mathrm{mcl}^{3} \\
5 \mathrm{mct}^{4}\end{array}$ & $\begin{array}{c}100 c^{5} \\
\text { total }\end{array}$ & $\begin{array}{l}100 \mathrm{Ci}^{6} \\
10 \mathrm{Ci}^{7}\end{array}$ & & & $1.85 \mathrm{mCl}$ & $.01 \mathrm{mci}^{9}$ & & & $\begin{array}{c}2 \mathrm{Ci}^{11} \\
100 \mathrm{mCi}^{12}\end{array}$ & $\begin{array}{c}400 \mathrm{Ci} \\
\\
200 \text { note } \\
286 \\
\end{array}$ \\
\hline$M n-54$ & & & & & $6.5 \mathrm{nCl} / \mathrm{g}$ & & & & & & \\
\hline $\mathrm{Na}-22$ & & & & & 780pCi/g & & & & & & \\
\hline $\mathrm{Nb}-94$ & & & & & 160pCV/g & & & & & & \\
\hline $\mathrm{Ni}-59$ & & & & & $700 \mathrm{pCi} / \mathrm{g}$ & & & & & & \\
\hline $\mathrm{Ni}-63$ & $100 \mathrm{mCi}$ & & & & $.002 \mathrm{mCi} / \mathrm{g}$ & & & & & & \\
\hline Np-237 & & & $1 \mathrm{Ci}$ & & 2nCi/g & & & & & & \\
\hline P-32 & & & & $16 \mathrm{mCi}$ & & & & & & & \\
\hline P-33 & & & & $5 \mathrm{mCi}$ & & & & & & & \\
\hline Pa-231 & $100 \mathrm{mCi}$ & & & & & & & & & & \\
\hline $\mathrm{Pb}-210$ & & & & & $230 \mathrm{nCl} / \mathrm{g}$ & & & & & & \\
\hline Po-210 & & & & & $20 \mathrm{nCi} / \mathrm{g}$ & & & & & & $11 \mathrm{Ci}$ \\
\hline Pr-147 & $100 \mathrm{mCi}$ & & & & & & & & & & \\
\hline $\mathrm{Pu}$ & & & & & & & & & $10 \mathrm{~g}$ & $200 \mathrm{~g}$ & $200 \mathrm{~g}$ \\
\hline Pu-238 & & & & & $10 \mathrm{nCi} / \mathrm{g}$ & & & & & & \\
\hline Pu-239 & & & & & $9.9 \mathrm{nCi} / \mathrm{g}$ & & & & & & \\
\hline Pu-240 & & & & & $10 \mathrm{nCi} / \mathrm{g}$ & & & $1 \mathrm{mCi}$ & & & \\
\hline Pu-241 & & & & & 350nCi/g & & & $1 \mathrm{mCi}$ & & & \\
\hline Pu-242 & & & & & $10 \mathrm{nCi} / \mathrm{g}$ & & & & & & \\
\hline Ra-226 & $100 \mathrm{mCi}$ & & & & $2 \mathrm{nCi} / \mathrm{g}$ & & & $.1 \mathrm{mCi}$ & & & \\
\hline Ra-228 & $100 \mathrm{mCi}$ & & & & $1.8 \mathrm{nCi} / \mathrm{g}$ & & & & & & $11 \mathrm{Ci}$ \\
\hline Ru-106 & & & & & 19nCi/g & & & & & & \\
\hline s-35 & & & & $1 \mathrm{mCi}$ & & & & & & & \\
\hline$S b-124$ & & & & & $790 \mathrm{pCi} / \mathrm{g}$ & & & & & & \\
\hline Sb-125 & & & & & $5300 \mathrm{pCi} / \mathrm{g}$ & & & & & & \\
\hline Sn-113 & & & & & $730 \mathrm{nCl} / \mathrm{g}$ & & & & & & \\
\hline Sr-90 & & & & & $20 \mathrm{nCi} / \mathrm{g}$ & & & $1 \mathrm{mCi}$ & & & \\
\hline Tc-99 & & & & & $100 \mathrm{nCl} / \mathrm{g}$ & & & & & & \\
\hline Thnat & & & & & & & & $15 \mathrm{mCi}$ & $200 \mathrm{mCi}$ & & \\
\hline Th-230 & & & & & $15 \mathrm{nCl} / \mathrm{g}$ & $1.85 \mathrm{mCi}$ & & & & & \\
\hline Th-232 & & & & & $680 \mathrm{pCi} / \mathrm{g}$ & & & & & & $11 C i$ \\
\hline
\end{tabular}


Appendix D VENDOR RADIOACTIVE MATERIAL LICENSE UMIT PROFILE'

\begin{tabular}{|c|c|c|c|c|c|c|c|c|c|c|c|}
\hline & ARS & $\begin{array}{l}\text { ALARON } \\
\text { Corp. }\end{array}$ & AEC & $\begin{array}{l}\text { COGNI } \\
\text { S, Inc. }\end{array}$ & $\begin{array}{l}\text { Envirocare } \\
\text {, Inc. }\end{array}$ & $\mathbf{F T}$ & Hazen & КCT & $\pi$ & RUST & SEG $^{13}$ \\
\hline$u$ & & & & & & $1.85 \mathrm{mCi}$ & & & & & $1.1 \mathrm{Ci}$ \\
\hline $\mathrm{U}-233$ & & & $200 \mathrm{~g}$ & & & & & & $10 \mathrm{~g}$ & $200 \mathrm{~g}$ & $200 \mathrm{~g}$ \\
\hline U-234 & & & & & $37 \mathrm{nCl} / \mathrm{g}$ & & & & & & \\
\hline U-235 & & $1000 \mathrm{~kg}$ & $350 \mathrm{~g}$ & & TropCi/g & & & & $200 \mathrm{~g}$ & $350 \mathrm{~g}$ & $350 \mathrm{~g}$ \\
\hline U-236 & & & & & $36 \mathrm{nCV}_{\mathrm{g}}$ & & & & & & \\
\hline U-238 & & & & & $28 \mathrm{nCV} / \mathrm{g}$ & & & & & & \\
\hline Unat & & & & & $18 \mathrm{nCV} / \mathrm{g}$ & $1.85 \mathrm{mCi}$ & & $60 \mathrm{mCl}$ & $200 \mathrm{mCi}$ & $1000 \mathrm{lbs}$ & $110 \mathrm{Ci}$ \\
\hline Udep & & & & & $110 \mathrm{nCi} / \mathrm{g}$ & $1.85 \mathrm{mCi}$ & & $10 \mathrm{mCi}$ & $200 \mathrm{mCi}$ & & \\
\hline $\mathrm{Zn}-65$ & & & & & $11 n \mathrm{ni} / \mathrm{g}$ & & & & & & \\
\hline
\end{tabular}

1 - Information presented from vendor survey conducted 3/17/95 through 3/29/95. Amounts depicted represent total amount of material allowed at any one time.

2 - Mixed activation and fission products

3 - Atomic numbers 93-96

4 - Atomic numbers $1-91$ (except natural thorium)

5 - Atomic numbers 1-96 (Fixed or removable contamination and sealed sources)

6 - Atomic numbers $3-83$ (excluding C-14)

7 - Atomic numbers $82-91$ (excluding source materia)

8 - License application for renewal pending with state

9 - Atomic numbers 1-96

10. Maximum average concentration in waste for disposal

11. Atomic numbers 2-92

12 - Atomic numbers 93 and above

13 - Radioactive materials with atomic numbers $84-91$ inclusive (no ${ }^{210} \mathrm{Po},{ }^{226} \mathrm{Ra}$, or ${ }^{232} \mathrm{Th}$ ); $1.1 \mathrm{Ci}$.

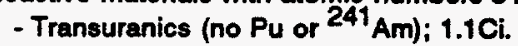

- Any radioactive material (except SNM) in sealed source form. No single source to exceed $5 \mathrm{mCl}$. Total not to exceed $10 \mathrm{mCl}$.

- Any other single sources maintained at SEG $>5 \mathrm{mCl}$ are licensed individually. 